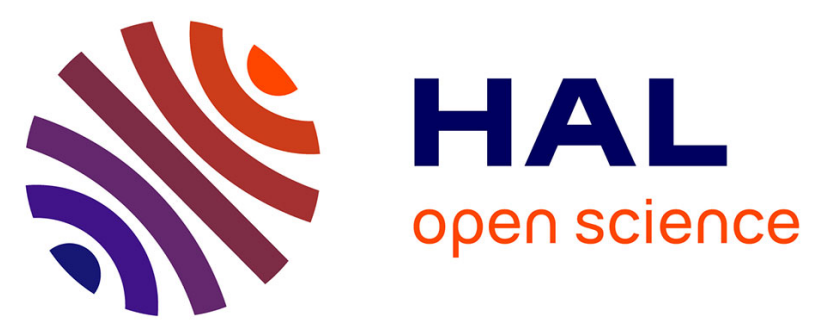

\title{
The Safety of Medications used to Treat Peripheral Neuropathic Pain, Part 2 (Opioids, Cannabinoids and Other Drugs): review of Double-Blind, Placebo-Controlled, Randomized Clinical Trials
}

Mélissa Cuménal, Marie Selvy, Nicolas Kerckhove, Célian Bertin, Margaux

Morez, Christine Courteix, Jérôme Busserolles, David Balayssac

\section{To cite this version:}

Mélissa Cuménal, Marie Selvy, Nicolas Kerckhove, Célian Bertin, Margaux Morez, et al.. The Safety of Medications used to Treat Peripheral Neuropathic Pain, Part 2 (Opioids, Cannabinoids and Other Drugs): review of Double-Blind, Placebo-Controlled, Randomized Clinical Trials. Expert Opinion on Drug Safety, 2020, pp.1-18. 10.1080/14740338.2021.1842871 . hal-02997543

\author{
HAL Id: hal-02997543 \\ https://hal.uca.fr/hal-02997543
}

Submitted on 10 Nov 2020

HAL is a multi-disciplinary open access archive for the deposit and dissemination of scientific research documents, whether they are published or not. The documents may come from teaching and research institutions in France or abroad, or from public or private research centers.
L'archive ouverte pluridisciplinaire HAL, est destinée au dépôt et à la diffusion de documents scientifiques de niveau recherche, publiés ou non, émanant des établissements d'enseignement et de recherche français ou étrangers, des laboratoires publics ou privés. 
The safety of medications used to treat peripheral neuropathic pain, part 2 (opioids, cannabinoids and other drugs): review of double-blind, placebocontrolled, randomized clinical trials

\section{Authors}

Mélissa Cuménal ${ }^{1}$, Marie Selvy², Nicolas Kerckhove², Célian Bertin², Margaux Morez Christine Courteix ${ }^{1}$, Jérôme Busserolles ${ }^{1}$, David Balayssac ${ }^{2}$

1. Université Clermont Auvergne, INSERM U1107 NEURO-DOL, Clermont-Ferrand, F63000 Clermont-Ferrand, France.

2. Université Clermont Auvergne, CHU Clermont-Ferrand, INSERM U1107 NEURO-DOL, Clermont-Ferrand, F-63000 Clermont-Ferrand, France.

3. Université Clermont Auvergne, CHU Clermont-Ferrand, INSERM U1107 NEURO-DOL, Institut Analgesia, Clermont-Ferrand, F-63000 Clermont-Ferrand, France.

\section{Corresponding author}

David Balayssac

INSERM U1107, NEURO-DOL

Laboratoire de Toxicologie, UFR de Pharmacie

28, place Henri Dunant, 63000 Clermont-Ferrand, France

Phone : +33473178041

dbalayssac@chu-clermontferrand.fr 


\title{
1 The safety of medications used to treat peripheral neuropathic pain,
}

2 part 2 (opioids, cannabinoids and other drugs): review of double-blind,

3 placebo-controlled, randomized clinical trials

4

5

6

7

8

\begin{abstract}
Introduction
Peripheral neuropathic pain is a highly disabling condition for patients and a challenge for physicians. Although many drugs have been assessed in scientific studies, few have demonstrated clear clinical efficacy against neuropathic pain. Moreover, the paucity of data regarding their safety raises the question of the benefit-risk ratio when used in patients experiencing peripheral neuropathies.
\end{abstract}

\section{Areas covered}

We conducted a review of double-blind, placebo-controlled, randomized clinical trials to assess the safety of medications used to treat peripheral neuropathic pain. This second review was focused on opioids, cannabinoids, and other medications. The aim was to provide an overview of the treatment-emergent adverse events (TEAEs) $(\geq 10 \%)$ and the serious adverse effects described in clinical trials.

\section{Expert opinion}

Opioids and cannabinoids had significantly more TEAEs than placebos. Locally administered analgesics, such as capsaicin, lidocaine, botulinum toxin A seemed to have the most acceptable safety with only local adverse effects. The results for NMDA antagonists were inconclusive since no safety report was available. Less than half of the studies included presented a good description of adverse effects that included a statistical comparison versus a placebo group. Major methodological improvements must be made to ameliorate the assessment of medication safety in future clinical trials.

Keywords: drug-related side effects and adverse reactions; neuropathic pain; randomized controlled trials; peripheral nervous system diseases 


\section{$1 \quad$ Article highlights box}

2 - Double-blind, placebo-controlled, randomized clinical trials are reviewed.

3 - We specifically focus on the adverse effects of opioids, cannabinoids, NMDA

4 antagonists, topical analgesics and botulinum toxin A medications used to treat peripheral neuropathic pain.

6 - Adverse drug reactions are under-reported in most clinical trials.

$7 \quad$ - We recommend that a detailed safety assessment of medications should be mandatory for clinical trials on peripheral neuropathic pain. 


\section{1. Introduction}

2 Regarding the management of neuropathic pain, the Neuropathic Pain Special Interest

3 Group (NeuPSIG) of the International Association for the Study of Pain (IASP),

4 presented strong recommendations for gabapentin, gabapentin-extended

5 release/enacarbil, pregabalin, serotonin and noradrenaline reuptake inhibitors (SNRIs),

6 duloxetine/venlafaxine, and tricyclic antidepressants (TCAs), as first-line therapies, and

7 weak recommendations for $8 \%$ capsaicin and lidocaine patches, tramadol, botulinum

8 toxin-A (subcutaneous), and strong opioids, which were recommended as second- or

9 third-line therapies [1]. The NeuPSIG highlighted the safety and tolerability of these

10 medications, which were low to moderate for TCAs, tramadol, and strong opioids;

11 moderate for the SNRIs duloxetine and venlafaxine; moderate to high for pregabalin,

12 gabapentin, gabapentin extended release/enacarbil and capsaicin $8 \%$ patches; and high

13 for lidocaine patches and botulinum toxin-A (subcutaneous) [1]. Consequently, most of

14 the recommended medications for the treatment of neuropathic pain had moderate

15 safety and tolerability, underlining that in addition to the difficulty of identifying

16 effective treatments for neuropathic pain, the safety of these treatments gives rise for

17 concern [1]. Moreover, the American Society of Clinical Oncology's (ASCO)

18 recommendations for the prevention and the management of chemotherapy-induced

19 peripheral neuropathy (CIPN) suggested that no agent could be recommended for the

20 prevention of CIPN, and included only a moderate recommendation for duloxetine

21 regarding its treatment [2]. The authors of these recommendations also underlined the

22 paucity of data available on adverse effects in clinical trials [2].

23 An initial review on the safety of antidepressant and antiepileptic medications in

24 the treatment of peripheral neuropathic pain, based on double blind randomized clinical

25 trials, showed that the most detailed description of the safety profile of any of these 
1 drugs concerned duloxetine [3]. Among the studies included, the most commonly

2 reported adverse effects were dizziness, drowsiness, nausea, and constipation. But only

$320.0 \%$ of the studies included provided a good description of adverse effects including a

4 statistical comparison versus a placebo group [3], reflecting the lack of robust safety

5 data in clinical trials mentioned by the NEUPSIG and the ASCO [1,2].

6 The aim of this second review was to assess the safety profile of opioids,

7 cannabinoids and other medications used to treat peripheral neuropathic pain.

9 2. Methods

10 2.1. Protocol

11 The protocol of this review was not registered. The safety of medications used to treat

12 peripheral neuropathic pain was assessed based on results from clinical trials assessing

13 medications compared with a placebo, and a randomized double-blind design.

\subsection{Eligibility criteria}

16 A bibliographic search was performed to extract original articles on clinical trials

17 assessing opioids or cannabinoids or other medications (except antidepressants and

18 antiepileptics) for the treatment of peripheral neuropathic pain.

The inclusion criteria were established to meet the following PICOS items:

20 patients without limit of age, patients with peripheral neuropathic pain, treated by

21 opioids or cannabinoids or other medications (single therapy and chronic treatment for

22 at least 1 week, except for botulinum toxin injection, ketamine infusion and capsaicin

23 application, and follow-up of at least 1 week), compared with a placebo, and a

24 randomized double-blind design. No specific outcome was defined for the inclusion 
1 criteria, whatever the description of treatment-related adverse events was. Studies were

2 included and analyzed only if the full-text was available and in English.

The exclusion criteria specified restrictions on publication types (exclusion of

4 reviews/meta-analyses, letters to the editor, study protocols, and case reports/case

5 series), therapeutic assessments (exclusion of pathophysiology and epidemiology

6 studies in the fields of neurology, oncology, endocrinology, infectious disease,

7 rheumatology, preclinical studies), and medication assessments (exclusion of massage,

8 acupuncture, electrostimulation, and physical activity, meditation, and cognitive

9 strategies). Studies were excluded if they were focused on central pain or pain other

10 than peripheral neuropathic pain or unknown origin. Studies assessing pharmacokinetic

11 parameters, drugs in development (drug identified only by a code), drug combinations,

12 phase 1 trials, and healthy volunteer trials were excluded. Finally, medications assessed

13 in 3 or less publications were excluded.

\subsection{Information sources and search}

16 A bibliographic search of the PUBMED database (www.ncbi.nlm.nih.gov/pubmed) was

17 performed. Two data extractions were carried out in the same time frame $(01 / 01 / 2000-$

18 13/02/2019). The first data extraction, focused on peripheral neuropathy, was performed

19 with the following keywords "peripheral neuropathy" and PUBMED filters: clinical

20 trials, human, and English. The second data extraction, focused on neuropathic pain,

21 was performed with the following keywords sequence ((((“neuropathic pain”) AND

22 randomized) AND controlled) NOT mice[Title]) NOT rats[Title] and PUBMED filters

23 for "English" and "excluding review". All duplicate publications were removed

24 between the first and the second extraction. The literature analysis was limited to the

25 publications extracted from PUBMED. 


\section{$1 \quad$ 2.4. Study selection}

2 All PUBMED study identification numbers (PMID) were extracted from PUBMED and

3 collated in Zotero software (Roy Rosenzweig Center for History and New Media) to

4 create a Zotero bibliographic database including the following details for each

5 publication: authors, title, journal, year, and abstract. This Zotero bibliographic database

6 was thereafter extracted to Excel software (Microsoft) for analysis. An initial

7 publication selection based on title and abstract was performed by authors NK and DB.

8 After this first study selection, all the authors performed a second study selection based

9 on the full-text of the publication and in accordance with the inclusion/exclusion

10 criteria. If a discrepancy with respect to the inclusion/exclusion criteria was noted for a

11 publication, consensus between the authors was sought on whether to include or

12 withdraw the publication.

\subsection{Data collection process and data items}

15 The full-texts of the selected studies were analyzed and the following items were

16 collected: authors' names, study design, drug/comparator, drug dose, number of

17 patients, duration of treatment, type of peripheral neuropathy, description or not of treatment-emergent adverse events (TEAEs), list of TEAEs in study drug arm ( $\geq 10 \%$ of patients), statistical comparison of TEAEs between groups, serious adverse events

20 (SAEs) related to the study drug, dropout rate due to TEAEs in study drug arm, drug 21 efficacy and PMID.

\subsection{Risk of bias in individual studies and across studies}

24 No risk of bias was assessed across the studies included. However, the quality of the 25 safety assessment was considered and discussed in the overall analysis of the studies. 


\section{2.7. Summary measures and synthesis of results}

3 The analyzed items were collected and presented in synthetic and harmonized tables by

4 pharmacological classes and international non-proprietary names. All the cited adverse

5 effects and statistical analyses ( $\mathrm{p}$-values) were derived from the studies included.

7 3. Results

8 Among the 2,148 publications identified, 50 publications describing double-blind,

9 placebo-controlled, randomized clinical trials of opioids (13 publications), lidocaine ( 9

10 publications), cannabinoids (8 publications), capsaicin (7 publications), botulinum toxin

11 (5 publications), ketamine (4 publications), and memantine (4 publications) medications

12 were included and analyzed in this review (Figure 1).

14 3.1. Opioids

15 Opioids, derived from Papaver somniferum, commonly known as the opium poppy,

16 have been known and used for thousands of years [4]. Opioids bind to specific opioid

17 receptors in the nervous system and other tissues. There are three principal classes of

18 opioid receptors, $\mu, \kappa, \delta$ (mu, kappa, and delta). They are found principally in the central

19 and peripheral nervous system and the gastrointestinal tract. These receptors mediate

20 both the psychoactive and the somatic effects of opioids. These drugs currently remain a

21 reference for the management of moderate to severe acute pain, while they sometimes

22 remain controversial for the management of chronic pain [5]. Nevertheless, events over

23 the last few decades and the recent opioid crisis in North America and most developed

24 countries [6-8], have highlighted their many therapeutic limitations and adverse effects.

25 Concerns about long-term adverse effects, such as physical dependency, and prescribed 
1 opioid use disorder, can limit their use in patients with chronic non-cancer related pain

2 [9-12]. The main opioids used clinically to treat neuropathic pain are morphine,

3 tramadol, oxycodone, tapentadol and fentanyl. According to NeuPSIG

4 recommendations, these opioids are recommended as second to third line therapies to

5 treat neuropathic pain [13] since their benefit-risk ratio is less than optimal due to their

6 many adverse effects and their contrasting efficacy for treating neuropathic pain [14].

7 Based on highly evidence-based clinical studies (randomized, double-blind, and

8 placebo-controlled), we selected thirteen clinical studies, between 2000 and today, for

9 our analysis of opioid-induced adverse effects in the treatment of peripheral neuropathic

10 pain (Table 1). These studies included a total of 1582 patients: four of them evaluated

11 tapentadol [15-18], one fentanyl [19], two oxycodone [20,21], two tramadol [22,23],

12 one buprenorphine [24], two methadone [25,26] and one morphine [27] (Table 1).

\subsubsection{Tapentadol (Table 1)}

In 828 patients with neuropathic pain, the efficacy and safety of tapentadol were evaluated after 4-12 weeks of treatment, with doses ranging from 50 to $500 \mathrm{mg}$ daily [15-18]. The doses used in these studies were in accordance with the recommendations (100 to $250 \mathrm{mg}$ orally twice a day). The results obtained showed that 70.9 to $86.7 \%$ of patients who received tapentadol had TEAEs, including mainly nausea, drowsiness, constipation, and vomiting. The drop-out rate due to TEAEs and the frequency of occurrence of SAEs ranged from 0.0 to $11.4 \%$ and from 4.8 to $5.1 \%$, respectively. None of the TEAEs were statistically compared to a placebo in terms of frequency of occurrence. Concerning analgesic efficacy, the studies showed a modest effect of tapentadol compared to a placebo in peripheral neuropathic pain [15-18]. 


\subsubsection{Tramadol (Table 1)}

2 The two studies evaluating tramadol were conducted with 100 patients with cancer or

3 cancer treatment related peripheral neuropathic pain [22,23]. The tramadol doses used

4 ranged from 1-1.5 mg/kg every 6 hours for 45 days or $200-400 \mathrm{mg} /$ day for 4 weeks

$5 \quad[22,23]$. Only the study of Arbaiza et al. showed an average of $67.0 \%$ of patients

6 receiving tramadol who reported an adverse effect, and the drop-out rate due to adverse

7 effects was $17.0 \%$ [23]. Among the adverse effects described in these two studies, the

8 majority were reported as nausea, dizziness, vomiting, constipation, fatigue, and sleep

9 disorders. SAEs were reported by from $1.6 \%$ to $17.0 \%$ of patients. None of these studies

10 carried out a statistical comparison of the frequency of adverse effects with the placebo

11 group. Concerning the efficacy of tramadol, these two studies were positive for

12 peripheral neuropathic pain [22,23]. SPC. 


\subsubsection{Oxycodone (Table 1)}

2 The studies, involving 318 patients, evaluated the analgesic effect of oxycodone in

3 patients with diabetic neuropathic pain [20,21]. These studies evaluated daily doses of

4 oxycodone ranging from 10 to $60 \mathrm{mg} /$ day for 6 weeks. The doses used were in

5 accordance with the recommendations. TEAEs were reported only in the study of

6 Gimbel et al. and $96.0 \%$ of patients declared TEAEs, mainly constipation, nausea,

7 dizziness, drowsiness, pruritus, dry mouth, and vomiting [21]. The SAE rate in this

8 study was $4.9 \%$ and the drop-out rate was $5.2 \%$. No statistical comparison with a

9 placebo was made in this study [21]. The main TEAEs observed were consistent with

10 those of SPC. Oxycodone significantly reduced peripheral neuropathic pain in these 2

11 studies [20,21].

12

\subsubsection{Morphine (Table 1)} neuropathic pain was demonstrated in this study [27]. 


\section{1}

2 Two studies evaluated methadone on a total of 33 patients with various peripheral

3 neuropathic pains [25,26]. The dose evaluated was $10-20$ or $30 \mathrm{mg}$ daily over 4 weeks

4 or 40 days, and conformed with the doses recommended in clinical practice. The results

5 showed that patients reported several TEAEs, mainly nausea, dizziness and drowsiness

$6 \quad[25,26]$. Only the study of Harrison et al. demonstrated that $40.0 \%$ of patients elicited

7 TEAEs [25]. No statistical comparison with placebo was made in these studies. The

8 analgesic efficacy of methadone in peripheral neuropathic pain was not demonstrated in

9 these two studies [25,26].

10

\section{3.1.7. Buprenorphine (Table 1)}

12 The only study evaluating buprenorphine was conducted by Simpson et al. on a total of 13186 patients with diabetic neuropathic pain [24]. The dose evaluated was $10-40 \mu \mathrm{g} / \mathrm{h}$ using transdermal patches over 12 weeks. The recommended doses in clinical practice are $5-40 \mu \mathrm{g} / \mathrm{h}$. The results showed that $93.6 \%$ of patients reported an adverse effect, mainly nausea and constipation. No statistical comparison with a placebo was made in this study. The analgesic efficacy of buprenorphine in peripheral neuropathic pain was not demonstrated in this study (intent-to-treat analysis), mainly explained by the occurrence of TEAEs and related drop-outs [24].

\subsection{Cannabinoids}

Like opioids, cannabinoids have been known and used since antiquity, both for medical and recreational purposes. They are mainly composed of the phytocannabinoid tetrahydrocannabinol (THC) and cannabidiol (CBD) is another major constituent of the plant [28]. Synthetic cannabinoids are manufactured artificially and newer compounds 
1 are no longer related to natural cannabinoids or are based on the structure of the

2 endogenous cannabinoids [29]. Cannabinoids produce their physiological and

3 behavioral effects mainly via two types of cannabinoid receptors, termed CB1 and CB2

4 [30]. Currently, the use of cannabinoids to treat neuropathic pain, and more broadly

5 chronic pain, remains controversial and their medical use remains limited to a few

6 countries in the world, mainly in cancer support care. Among the studies selected in this

7 review, 8 studies, involving a total of 537 patients, evaluated tetrahydrocannabidiol

8 (THC) / cannabidiol (CBD) [31-34], nabilone [35], Cannabis cigarette [36,37] and CT-

931 ',1'dimethylheptyl- $\Delta 8$-tetrahydrocannabinol-11-oic acid [38] (Table 2).

\subsubsection{Tetrahydrocannabidiol (THC) / cannabidiol (CBD) (Table 2)}

12 Four studies with 222 patients treated with inhaled THC/CBD(2-12 inhalations/day;

$1327 \mathrm{mg} / \mathrm{ml} / 25 \mathrm{mg} / \mathrm{ml}$, spray of $100 \mu \mathrm{L} ; 2.7 \mathrm{mg} / 2.5 \mathrm{mg}, 11$ inhalations/day) were conducted over 4 weeks until 15 weeks [34,31-33]. They showed that the main TEAEs observed were fatigue (15-43.8\%), dizziness (28.6-37.5\%), nausea (17-37.5\%) and dry mouth (17.5-31.3\%). However, none of these TEAEs were statistically compared to a placebo. The drop-out rate due to TEAEs was about 18 and 19\% in $2[34,31]$ of the 4 studies. THC/CBD association was effective (primary endpoint) in two studies [31,34]

19 and not in the two other studies [32,33].

\subsubsection{Nabilone (Table 2)}

22 Only one study tested nabilone 1-4 mg/day versus placebo in a monocentric setting with few patients (13 patients treated with nabilone) [35]. The overall TEAE was about 54\% but not compared to a placebo group. The drop-out rate for TEAEs corresponded to the rate of SAEs in this study, i.e. 5.4\%. In the selected study, nabilone was effective [35]. 
2 3.2.3. Cannabis cigarette (Table 2)

3 Two studies evaluated the effect of cannabis cigarettes (1-8\% $\Delta-9-$ THC and $3.56 \% \Delta-9$ -

4 THC) several times a day in 41 patients versus a placebo group over 7 weeks and 12

5 days [36,37]. In the first study, the main TEAE was tachycardia (46\%) and not

6 compared to placebo groups, with a drop-out rate of $12.5 \%$ [36]. In the second study,

7 the main TEAEs were anxiety, sedation, disorientation, confusion and euphoria. No

8 proportion of TEAEs was provided in the study, but these TEAEs were significantly

9 greater than those of the placebo group. About $4.0 \%$ of patients treated with cannabis

10 cigarettes developed SAEs, but no patient dropped-out due to TEAEs [37]. Cannabis

11 cigarettes were effective (primary endpoint) in the two selected studies [36,37].

\subsubsection{CT-3 1',1'dimethylheptyl-48-tetrahydrocannabinol-11-oic acid (Table 2)}

14 Only one study assessed CT-3 1',1'dimethylheptyl- $\Delta 8$-tetrahydrocannabinol-11-oic acid

15 administered by capsule at 40-80 mg/day in 10 patients versus a placebo for 1 week

16 [38]. There are no details on TEAEs but overall TEAEs were reported to be

17 significantly higher than those of the placebo group. SAEs were reported in $10.0 \%$ of

18 patients as was the dropout rate [38]. In the selected study, CT-3 1',1'dimethylheptyl-

$19 \Delta 8$-tetrahydrocannabinol-11-oic acid was effective (primary endpoint) [38].

\subsection{NMDA antagonists}

22 N-Methyl-D-Aspartic Acid (NMDA) antagonists act, as their name suggests, by blocking NMDA receptors (NMDARs). NMDARs are ionotropic receptors, activated in physiological condition by glutamate and glycine, and are essential for normal brain

25 function including memory and synaptic plasticity. They are the only glutamate 
1 receptors to be specifically activated by the pharmacological agonist NMDA. The

2 activation of NMDARs has been associated with neuropathic pain and result from

3 increased spinal neuron sensitization, leading to a heightened level of pain. NMDA

4 antagonists may reduce pain by reducing central sensitization. Moreover, NMDA

5 antagonists may reduce opioid tolerance. Several NMDAR antagonists are available,

6 mainly ketamine, memantine, and dextromethorphan used for pain management. These

7 antagonists are important modulators of chronic pain and have been shown to be useful

8 in preventive analgesia by reducing acute postoperative pain, analgesic consumption, or

9 both when added to more conventional means of providing analgesia, such as opioids

10 and nonsteroidal anti-inflammatory drugs, in the perioperative period. The severity and

11 frequency of adverse effects depend on affinity for the NMDAR [39]. This review

12 reports 8 studies including a total of 456 patients which evaluated ketamine [40-43] and

13 memantine [44-47] (Table 3).

\subsubsection{Ketamine (Table 3)}

16 Ketamine is used in high doses as a general anesthetic, and in low doses as an analgesic.

17 Ketamine is a phenylpiperidine, the racemic form of which is used clinically. It comprises similar amounts of two stereoisomers that have different pharmacological properties: the $\mathrm{S}(+)$ ketamine is four times more potent than the $\mathrm{R}(-)$ isomer, and is associated with faster awakening and a decrease in hallucinatory phenomena $[48,49]$. Three studies were conducted on a total of 250 patients to evaluate the efficacy of the perioperative administration of $\mathrm{S}(+)$ ketamine [42] and $\mathrm{R}(-)$ ketamine (143 treated patients) $[40,41]$ on neuropathic pain after thoracotomy. Ketamine was injected locally before incision and infused via the epidural [40] or intravenous [40-42] route during and after the surgical procedure with different doses, ranging from 0.5 to $1 \mathrm{mg} / \mathrm{kg}$ for 
1 induction and 0.1 to $1 \mathrm{mg} / \mathrm{kg}$ for maintenance infusion during surgery. Patients were

2 followed up to 6 months post-surgery. The results of these studies showed that patients

3 receiving ketamine reported adverse effects in $12.1-51.1 \%$ of cases. The main adverse

4 effects related to ketamine were nightmares/psychotomimetic effects, pruritus,

5 hypotension and dry mouth sensation. Patients who had received epidural ketamine

6 experienced more cognitive and visual effects such as nightmares and diplopia than

7 when administrated by the intravenous route, but there was no statistical difference. The

8 TEAEs were statistically compared to a placebo but there was no difference in terms of

9 frequency of occurrence. Moreover, the rate of drop-outs due to adverse effects was null

10 in these studies.

11 An additional study included a total of 47 patients and 22 patients receiving

12 ketamine in $1 \%$ cream form with 3 applications / day, compared to a placebo for 3

13 weeks to relieve various peripheral neuropathic pains [43]. In this study patients

14 reported TEAEs in $30 \%$ of cases only in the ketamine group. The drop-out rate due to

15 TAEs for this study was $9.1 \%$. Finally, there were no statistical comparisons of TEAEs

16 with a placebo in terms of frequency of occurrence in any of the studies.

17 Concerning analgesic efficacy, the studies showed no significant effect

18 compared to placebo groups. The doses used in these studies were in accordance with

19 the recommendations ( 0.5 to $2 \mathrm{mg} / \mathrm{kg}$ for the first induction and 0.1 to $1 \mathrm{mg} / \mathrm{h} / \mathrm{kg}$ for

20 maintenance infusion during surgery) [50]. The main adverse effects reported (>10\%)

21 were also reported as very frequent $(>10 \%)$ and/or frequent $(1-10 \%)$ in the summary of

22 product characteristics (SPC). Nevertheless, some adverse effects indicated as very

23 frequent and/or frequent in SPC did not appear in the studies analyzed, such as

24 increased respiratory rate, erythema and morbilliform rash. 


\section{1}

2 Since the development of chronic neuropathic pain involves central sensitization and

3 NMDA receptor activation, well-tolerated uncompetitive NMDA receptor antagonists

4 such as memantine hydrochloride (NAMENDA) are of interest to clinicians. Memantine

5 is an amantadine derivative first synthesized in 1968 and approved in 2000 by the Food

6 and Drug Administration for the treatment of moderate to severe dementia in

7 Alzheimer's disease. Memantine is a low-affinity uncompetitive NMDA-receptor

8 antagonist which dissociates rapidly from the NMDA receptor channel after

9 inactivation, thereby causing minimal interference with normal physiological

10 transmission mediated by NMDA receptors. In addition to its rapid blocking /

11 unblocking kinetics, it is associated with high bioavailability and no cytochrome P-450

12 inhibition or CYP induction. The most common adverse reactions (incidence $\geq 5 \%$ and

13 higher than placebo) caused by memantine are dizziness, headache, confusion and

14 constipation. There is no described contraindication for memantine but it is

15 recommended to reduce the dose in patients with renal and hepatic impairment. Despite

16 its potential, a recent meta-analysis concluded that the use of memantine for chronic

17 pain is limited and uncertain [51]. In view of this, it was useful to consider the safety of

18 memantine in the management of neuropathic pain.

In the present review, we identified 4 double-blind, placebo-controlled,

20 randomized clinical trials that included a total of 112 patients and 71 patients receiving

21 oral memantine (from 10 to $40 \mathrm{mg}$ daily) or a placebo for a treatment duration from 4 to

2216 weeks [44-47]. Three of the 4 studies reported no positive therapeutic effects of

23 memantine on neuropathic pain [44-46]. Only one study reported TEAEs in more than

$2410 \%$ of the patients corresponding to dizziness, headache, nausea and drop-foot [47]. 
2 weeks) and the disparity of doses used (10 to $40 \mathrm{mg}$ ), the conclusions drawn from these

3 studies were limited and underlined the necessity for largescale clinical trials to

4 investigate such adverse effects.

\subsection{Capsaicin}

Capsaicin (6-nonenamide, N-[(4-hydroxy-3-methoxyphenyl) methyl]-8-methyl- (6E)), a natural alkaloid, extracted from the Solanaceae plant family (red chili peppers), selectively binds to the transient receptor potential vanilloid 1 (TRPV1), a ligand-gated, nonselective cation channel, predominantly expressed in unmyelinated $\mathrm{C}$ nerve fibers).

Opening the ion channel leads to depolarization and the production of action potentials, which are usually perceived as itching, pricking or burning sensations. Repeated applications or high concentrations give rise to a long-lasting effect, which has been termed 'defunctionalization' of nociceptor fibers. Defunctionalization is due to a number of effects that include temporary loss of membrane potential, inability to transport neurotrophic factors leading to phenotype alteration, and the reversible retraction of epidermal and dermal nerve fiber terminals [52]. Contrary to other natural irritants, capsaicin induces an initial pain response, followed by a lasting refractory state, traditionally referred to as desensitization in which the previously excited neurons are unresponsive not only to a repeated capsaicin challenge but also to various unrelated stimuli [53].

Low-concentration $(<1 \%)$ capsaicin creams might function as counterirritants. A Cochrane review from 2012 concluded there were insufficient data to draw any conclusions about the efficacy of low-concentration capsaicin cream in the treatment of neuropathic pain [54]. A high-concentration (8\%) patch was developed to increase the amount of capsaicin delivered to the skin, and improve tolerability. Rapid delivery is 
1 thought to improve tolerability because cutaneous nociceptors are 'defunctionalized'

2 quickly, and single application avoids both noncompliance and contamination of the

3 home environment with particles of dried capsaicin cream [55]. Its clinical use is

4 approved for peripheral neuropathic pain of diverse etiology in the European Union, and

5 for the treatment of post-herpetic neuralgia in the USA. A Cochrane review of ten clinical

6 studies with high-concentration topical capsaicin involving 2903 patients with post-

7 herpetic neuralgia, painful human immunodeficiency virus (HIV)-neuropathy and

8 peripheral diabetic neuropathy, found moderate or more substantial levels of pain relief

9 than control treatment [55].

10 The seven trials included in our analysis comprised a total of 580 patients (Table

11 4). Capsaicin was tested in diabetic neuropathic patients in three of them as a $0.025 \%$

12 (in 33 patients [56]) or $0.075 \%$ (in 21 patients [57]) lotion or as a $8 \%$ patch (in 186

13 patients [58]) versus a placebo for 8 to 12 weeks. One trial assessed capsaicin in low

14 concentration $(0.625 \%$ or $1.25 \%)$ patches versus a placebo or a $0.075 \%$ lotion in 5

15 diabetic neuropathic patients and 55 post herpetic neuropathic patients for 6 weeks [59].

16 Another trial assessed a 0.025 liposomal capsaicin lotion in 14 post herpetic neuropathic

17 patients for 6 weeks [60]. Yet another trial assessed a $0.1 \mathrm{mg}$ dose capsaicin injection in

1830 Morton's neuroma patients versus placebo (28 patients) [61]. A 0.075\% capsaicin

19 lotion was also assessed in $26 \mathrm{HIV}$-associated peripheral neuropathic patients versus

20 placebo for 4 weeks [62]. The number of positive studies (analgesic efficacy of

21 capsaicin compared to placebo) was only 3 (43\%). These positive effects were modest

22 and obtained for the $0.1 \mathrm{mg}$ dose in Morton's patients and the high dose (8\%) capsaicin

23 patch in diabetic subjects. Lower dose capsaicin patches gave inconsistent results in

24 Moon et al.'s trial since only the lower $(0.625 \%$ concentration $)$ resulted in a positive

25 effect, while the higher concentration patch (1.25\%) failed to have a significant 
1 analgesic effect [59]. TEAEs, mainly skin reaction at the administration site, were

2 observed in $46.6 \%$ to $87.5 \%$ of patients (among the six studies that evaluated overall

3 frequency), who reported at least one TEAE associated with capsaicin (of which $0.0 \%$

4 to 2.2 were considered serious), leading to dropouts in 2.2 to $33.3 \%$ of cases. The main

5 TEAEs observed were burning sensation (3-41.7\%) and erythema (1.1-11.1\%) (Table

$64)$. It was observed that the safety assessment of capsaicin was not performed in one

7 study.

Data obtained for low concentration capsaicin are in line with recent conclusions

9 made on the safety of these capsaicin preparations [54]. Hence, local skin irritation,

10 often mild and transient but possibly leading to withdrawal, was common, while

11 systemic adverse effects were rare when low concentration capsaicin lotions were

12 tested. Interestingly, liposomal topical capsaicin was tested in a small number of post-

13 herpetic patients [60] to increase the therapeutic index. This delivery system was

14 designed to deliver the medication to its target with fewer adverse effects.

15 Unfortunately, safety data are scarce. Further studies are thus needed with this type of

16 formulation. In Morton's neuroma subjects, a single dose of capsaicin injected locally

17 resulted in a significant decrease in pain, while the overall adverse effect profile of all

18 causalities and treatment-related characteristics was similar in both the capsaicin and

19 control groups. Given that this was an exploratory study, there is more to learn

20 regarding dosing, the control of procedure pain, and effect durability. Data obtained

21 with high concentration capsaicin were also in line with conclusions made recently

22 regarding the safety of these capsaicin preparations [55]. Hence, one 30-minute

23 capsaicin $8 \%$ patch treatment provides modest improvements in pain and sleep quality

24 versus a placebo in patients with painful diabetic peripheral neuropathy, whereas, apart

25 from application site reactions, TEAEs were similar between groups. This result is of 
1 importance in this particular condition. Hence, the clinical characteristics of painful

2 diabetic peripheral neuropathy which involve distal extremities in hands/feet have been

3 postulated as being unsuitable for the application of patch preparations with high

4 concentrations [63].

\section{$5 \quad$ 3.5. Lidocaine}

6 Lidocaine is an amide-type local anesthetic agent that acts by stabilizing neuronal

7 membranes. Lidocaine is a voltage-gated sodium channel inhibitor, which acts by

8 blocking the abnormal functioning of Nav1.7 and Nav1.8 sodium channels in the

9 dermal nociceptors of A delta and C fibers, thereby reducing the number of ectopic

10 discharges [64]. Other effects on keratinocytes and immune cells, or the activation of

11 irritant receptors (TRPV1 and TRPA1), may also contribute to the analgesic effect of

12 topical lidocaine [65]. Long-term use may cause a loss of epidermal nerve fibers [66].

13 Lidocaine is mainly used as a 5\% lidocaine patch and has demonstrated efficacy in a

14 variety of neuropathic pain conditions and in long-term treatment. It has an excellent

15 safety profile, does not require dose titration, and can easily be applied by the patient

16 [64]. However, these results must be mitigated by the results of the overview of

17 Cochrane Reviews of topical analgesics for acute and chronic pain in adults. They

18 showed very low quality but the findings were typically limited to single studies or

19 comparisons with sparse data [67].

20 Nine studies assessing lidocaine in peripheral neuropathic pain were included in 21 a review enrolling a total of 760 patients and 492 patients treated with lidocaine [68-76]

22 (Table 4). As can be seen three studies focused on various peripheral neuropathic pains

$23[69,70,73]$, two on postoperative neuropathic pain $[68,72]$, two on post-herpetic

24 neuropathic pain [71,76], one on HIV-associated neuropathy [74], and one on focal

25 peripheral neuropathic pain syndromes [75]. Six studies mentioned the use of a 5\% 
1 lidocaine patch applied 12-24 hours per day for 1 to 12 weeks [68,70-72,75,76], two

2 studies with a 5\% topical gel with one to two applications per day for 1 to 2 weeks

$3 \quad[73,74]$, and one with a $3 \mathrm{mg} / \mathrm{kg}$ lidocaine intravenous infusion once per week for 4

4 weeks [69]. One study did not report TEAEs [74], one study reported no TEAEs $\geq 10 \%$

5 [76], and one study did not report the frequency of overall TEAEs [72]. In other studies,

6 overall TEAEs for topical lidocaine ranged between $13.6 \%$ and $52 \%$ of lidocaine treated

7 patients. Only one study assessed the statistical significance of the overall TEAEs of

8 topical lidocaine, and found no difference compared to the placebo group [73]. The

9 main TEAEs for topical lidocaine were local reactions ranging from 11.6 to $21.9 \%$.

10 Only one study assessed the statistical significance of these TEAEs and found no

11 difference in comparison to the placebo group [72]. The study assessing lidocaine

12 infusion reported a $14.3 \%$ frequency of overall TEAEs with no significance in

13 comparison to the placebo group [69]. No SAEs were reported in the 6 studies

14 mentioning it [68-70,73-75]. Drop-out rates due to TEAEs were reported in 7 studies

15 and ranged between 0 and $7.0 \%$ [68-71,73-75].

16 Among the studies included, seven studies found positive results on peripheral

17 neuropathic pain [68-71,73,75,76] and two negative results [72,74].

\subsection{Botulinum toxin (BoNT)}

20 BoNT is protein group produced by Clostridium botulinum bacteria. Botulinum toxin A

21 (BoNT-A) and B (BoNT-B) are the most commonly used drugs. BoNT-A is currently

22 approved for several indications such as dystonia or seizures, and cosmetic treatments

23 [77]. BoNT-A enters the nerve ending, blocks exocytosis and acetylcholine secretion,

24 resulting in blocking muscle innervation at the neuromuscular junction and inducing

25 flaccid paralysis [77]. BoNT-A also reduces neuropathic pain. BoNT-A inhibits the 
1 secretion of pain mediators (substance $\mathrm{P}$, glutamate, and calcitonin gene related protein

2 (CGRP)) from the nerve endings and dorsal root ganglions (DRG), reduces local

3 inflammation around the nerve endings, deactivates sodium channels, and exhibits

4 axonal transport (for review see: Park and Park, 2017 [77]).

Among the publications selected, five publications assessing BoNT-A presented

6 results from double blind placebo controlled trials, three of them with parallel groups

7 [78-80] and the remaining two with a cross-over design [81,82] (Table 4). In these

8 studies, a total of 177 patients were included for the treatment of various peripheral

9 neuropathic and diabetic neuropathic pains, and 109 patients received one intradermal

10 injection of BoNT-A (50-190 U) [78,80-82] or two intradermal injections of BoNT-A

11 (until a maximum of $300 \mathrm{U}$ ) [79]. The follow-up of these patients was 3 weeks for one

12 study [80], 12 weeks for two studies [81,82], and 24 weeks for the two other studies

$13[78,79]$. All the studies concluded on significant and positive results of BoNT-A

14 relating to peripheral neuropathic pain [78-82]. One study did not provide safety data

15 on TEAEs [81]. The safety data available in the remaining studies mentioned very few

16 TEAEs, no TEAEs or less than $10 \%$ [80,82], and pain at the injection site which was,

17 however, not significant in comparison to the placebo groups $[78,79]$. No SAEs were

18 recorded in two studies $[79,82]$ and unknown in the three others $[78,80,81]$. No patient

19 dropped out of the studies due to TEAEs.

20 The safety profile of BoNT-A was assessed in four meta-analyses for trigeminal

21 neuralgia [83], painful temporomandibular disorders [84], upper limb spasticity after

22 stroke and traumatic brain injury [85], and overactive bladder [86]. None of these meta-

23 analyses found significant adverse effects related to BoNT-A injections between BoNT-

24 A and placebo groups [83-86]. 
2 neuropathic pain with few or no TEAEs reported in the studies selected.

\section{4. Conclusion}

7 Among the studies included, $12.0 \%$ (6) of them did not provide any information on

8 TEAEs, $34.0 \%$ (17) on SAEs, and $16.0 \%$ (8) on drop-out rates. Adverse events were

9 reported as secondary outcomes for $64 \%$ (32) of studies, as sporadic observations for

$1034 \%(17)$ of them. For one study (2\%), there was no information on adverse events.

11 Among the studies detailing TEAEs, 36.4\% (16) studies did not provide information on

12 the overall rate of TEAEs, and $47.7 \%$ (21) did not assess the statistical significance of

13 TEAE frequency in comparison with the placebo group.

Moreover, peripheral neuropathic pain, defined by the IASP as "pain caused by

15 a lesion or disease of the peripheral somatosensory nervous system", refers to a broad

16 range of clinical conditions that can be categorized as degenerative, traumatic,

17 infectious, metabolic, or toxic [87]. Regarding the trials included in this review, a clear

18 disequilibrium can be observed regarding the number of trials performed on patients

19 suffering from peripheral neuropathy of metabolic origin (28\% of studies focusing

20 specifically on diabetic neuropathy), of traumatic origin (12\% of studies focusing

21 specifically on postoperative neuropathic pain) and of infectious origin (14\% of studies

22 focusing specifically on HIV patients and $6 \%$ on post-herpetic neuropathy) in

23 comparison to other etiological origins. Moreover, $30 \%$ of studies included populations

24 of patients with peripheral neuropathic pain of various origins, making it difficult to

25 assess safety (and efficacy) for a specific type of peripheral neuropathy. Only one study 
1 included patients with CIPN, whereas this peripheral neuropathy is highly prevalent

2 among cancer patients and cancer survivors [88].

The safety of opioids was statistically assessed in only two publications. One

4 publication for tramadol showed a significantly higher overall frequency of TEAEs

$5(67 \%)$ than a placebo [23]. One publication relating to oxycodone showed significantly

6 higher frequencies of constipation (42.0\%), drowsiness (40.0\%), nausea (36.0\%),

7 dizziness (32.0\%), pruritus (24.0\%), vomiting (21.0\%), and dry mouth (16.0\%) than a

8 placebo [21]. In the light of the results of all the studies, the benefit-risk ratio of opioids

9 seems far from satisfactory for treating neuropathic pain. Since the analgesic efficacy of

10 opioids on neuropathic pain is subject to considerable uncertainty, [14] with a range of

11 TEAE frequency from 40.0 to $96.0 \%$ (SAEs: 0.0 to $17.0 \%$ ), opioids do not seem to be

12 favored for the treatment of peripheral neuropathic pain, not to mention the effects of

13 long-term tolerance, dependence and substance use disorder, which were not evaluated

14 in the studies selected. This observation is in line with the results of the various recent

15 meta-analyses [14,89-92].

16 Concerning prescribed opioid use disorder, the non-medical use of, and

17 dependence on, pharmaceutical drugs has been described as a major health problem. An

18 estimated 26 to 36 million people were using opioids in 2010 , with around half of them

19 using pharmaceutical opioids [93]. There are an estimated 15.6 million opioid

20 dependent people worldwide, and the global consumption of opioids is considered to be

21 increasing [94]. Prescribed opioid use disorder is a chronic relapsing condition with

22 significant cost to human life [95].

23 There are few or no studies that have actually compared the risks of opioid use

24 disorder between these different drugs. Nevertheless, Cepeda et al. [96], in a cohort

25 study using two claims databases, concluded that patients treated with tapentadol 
1 immediate release have a lower risk of receiving an abuse diagnosis and developing a

2 prescribed opioid use disorder than with oxycodone immediate release. Moreover, in

3 spite of providing an overall low rate of adverse events, tramadol was shown to have

4 considerable dependence and abuse potential. Given the contribution of the $\mu$-opioid

5 peptide receptor component to dependence and abuse, and considering the more

6 pronounced noradrenaline reuptake inhibition component of tapentadol, the analgesic

7 efficacy of tramadol is comparable to that of other strong opioids, but with considerably

8 fewer opioid adverse effects and less abuse potential. Its minimal serotonergic effect,

9 along with evidence of enhanced gastrointestinal tolerability and no negative effects on

10 neurogenesis, makes it a promising alternative for the treatment of chronic and

11 neuropathic pain. Moreover, unlike tramadol and oxycodone, tapentadol does not

12 depend on the CYP450 system to produce a more active metabolite [97]

The safety of cannabinoids was statistically assessed in only two publications

with significantly more TEAEs (without the frequency and details of these TEAEs) than placebo in one publication [38], and significantly more central nervous adverse effects such as anxiety, sedation, disorientation, confusion and dizziness (without frequency details) in another publication [37]. This is consistent with results presented by Aviram and Samuelly-Leichtag in their meta-analysis on the efficacy and safety of cannabis based medicines for pain management [98]. The main and significant TEAEs were: central nervous system-related adverse effects (risk ratio models $2.84[2.16,3.73], \mathrm{p}<$

210.001 , cannabis based medicines vs placebo) and the most prevalent were dizziness and 22 drowsiness; gastrointestinal-related adverse effects (risk ratio models 1.86 [1.43, 2.43], $23 \mathrm{p}=0.001$, cannabis based medicines vs placebo) and the most prevalent were nausea 24 and vomiting; psychological-related adverse effects (risk ratio models 3.07 [1.79, 5.26], $25 \mathrm{p}<0.001$, cannabis based medicines vs placebo); hearing related adverse effects (risk 
1 ratio models $3.25[1.58,6.67], \mathrm{p}=0.001$, cannabis based medicines vs placebo) of

2 which the most prevalent was tinnitus [98]. The safety of ketamine infusion was statistically assessed in three publications.

4 No information was provide on overall TEAEs, but the TEAEs were detailed and not

5 significantly different from a placebo [40-42]. The safety of topical ketamine was

6 assessed in only one publication and no TEAEs $\geq 10 \%$ were reported [43].

Very little information was available for memantine, since only one publication reported the frequency of occurrence of TEAEs but without statistical comparison to the placebo group [47].

The safety of topical capsaicin was statistically assessed in three publications, but none of them reported the overall frequency of TEAEs $[56,57,60]$. However, two of these studies reported significantly more local skin reactions $(14.7 \%-50 \%)$ with topical capsaicin than placebo $[56,57]$.

The safety of topical lidocaine was statistically assessed in three publications with overall TEAEs $(14.3 \%$ - 21.9\%) [69,73], and local skin reactions $(21.0 \%)$ [72] without significance in comparison to placebo

Safety of local injection of BoNT-A was statistically assessed in only two publications and reported non-significant pain at the injection site compared to placebo $[78,79]$. can be clearly drawn on the safety profiles of the medications analyzed.

\section{Expert opinion}

24 Based on the selected publication, locally administered analgesics, such as capsaicin,

25 lidocaine, and BoNT-A, seem to have the most acceptable safety with only local 
1 TEAEs, which is in accordance with the results of the NeuPSIG [1]. Importantly,

2 topical treatment are strictly limited to some peripheral neuropathic pain with presumed

3 local pain generator [1]. Capsaicin $8 \%$ patches and lidocaine patches are recommended

4 in second-line therapy for peripheral neuropathic pain [1]. BoNT-A is recommended in

5 third-line therapy and for specialist use [1]. Opioids and cannabinoids had significantly

6 more TEAEs than placebo. Tramadol is recommended as second-line therapy and

7 strong opioids as third-line therapy [1]. Tapentadol is not classified by the NeuPSIG

8 because of inconclusive results [1]. However, the prescription and use of opioids in the

9 context of the opioid crisis is still an unresolved issue associated with misuse, overdose

10 and death [99], and which have not been assessed in the selected publication. NeuPSIG

11 provides a weak recommendation against the use of cannabinoids for peripheral

12 neuropathic pain, mainly because of negative results, potential misuse, abuse, diversion

13 and long term mental health risks, particularly in susceptible individuals [1]. In this

14 review, the results obtained on NMDA antagonists were inconclusive because of a lack

15 of TEAE reported in the selected studies. NMDA antagonists are not classified by the

16 NeuPSIG, also because of inconclusive results [1].

17 As mentioned in our first review on antidepressant and antiepileptic medications

18 [3], the majority of the adverse effects related to medications used to treat peripheral

19 neuropathic pain are not life threatening, but they can significantly alter the quality of life

20 of patients, and be an obstacle to treatment adherence [3].

21 The main weakness of this review is related to the fact that many of the clinical

22 trials included in this review failed to sufficiently describe the safety of the drugs

23 evaluated. Although double-blind, placebo-controlled, randomized clinical trials were

24 included in this review, more than half of them did not provide a statistical analysis of

25 TEAE frequency. Consequently, caution must be taken when assessing the frequency of 
1 TEAEs in these studies. Moreover, their authors did not mention if the observed adverse

2 events were related to the medications evaluated, which may have contributed to an

3 overestimation of reported TEAEs. Many issues have been raised regarding the

4 assessment and reporting of drug safety during randomized clinical trials [100];

5 however, no gold standard of evidence for safety assessment has been defined.

6 Randomized clinical trials have a limited statistical power for TEAE assessment as

7 sample sizes are designed with the main objective of efficacy. In addition, the lack of

8 adequate ascertainment and classification of TEAEs leads to inconsistencies in their

9 reporting. The hyper-selection of patients through restrictive inclusion and exclusion

10 criteria leads to limited generalizability [100].

11 We encourage the publication of clinical trials in accordance with CONSORT

12 guidelines [101]; furthermore, authors should incorporate in their manuscript a table

13 describing all the observed adverse events, including the relationship between the

14 adverse events and treatments, serious TEAEs, the dropout rate related to TEAEs, and

15 the statistical significance of these TEAEs versus placebo. Since, major reasons for

16 early withdrawal in clinical trials of treatments for chronic pain include perceived lack

17 of efficacy and adverse events, careful consideration of the trial objectives should

18 determine the definition of the trial estimand, which in turn should inform methods used

19 to accommodate missing data in the statistical analysis [102].

The management of peripheral neuropathic pain is a largely unmet medical need

22 [1]. Pain physicians and patients are still waiting for pharmacological innovations that

23 will improve the safety of pain medications. 


\section{References}

[1] Finnerup NB, Attal N, Haroutounian S, et al. Pharmacotherapy for neuropathic pain in adults: a systematic review and meta-analysis. Lancet Neurol. 2015;14:162-173.

[2] Hershman DL, Lacchetti C, Dworkin RH, et al. Prevention and management of chemotherapy-induced peripheral neuropathy in survivors of adult cancers: American Society of Clinical Oncology clinical practice guideline. J Clin Oncol. 2014;32:1941-1967.

[3] Selvy $M$, Cuménal $M$, Kerckhove $N$, et al. The safety of medications used to treat peripheral neuropathic pain, part 1 (antidepressants and antiepileptics): review of double-blind, placebo-controlled, randomized clinical trials. Expert Opin Drug Saf. 2020;1-27.

[4] Brownstein MJ. A brief history of opiates, opioid peptides, and opioid receptors. Proc Natl Acad Sci USA. 1993;90:5391-5393.

[5] Rosenblum A, Marsch LA, Joseph $\mathrm{H}$, et al. Opioids and the treatment of chronic pain: controversies, current status, and future directions. Exp Clin Psychopharmacol. 2008;16:405-416.

[6] Manchikanti L, Helm S, Fellows B, et al. Opioid epidemic in the United States. Pain Physician. 2012;15:ES9-38.

[7] Gallagher H, Galvin D. Opioids for chronic non-cancer pain. BJA Education. 2018;18:337-341.

[8] Häuser W, Schug S, Furlan AD. The opioid epidemic and national guidelines for opioid therapy for chronic noncancer pain: a perspective from different continents. Pain Rep. 2017;2:e599.

[9] Kissin I. Long-term opioid treatment of chronic nonmalignant pain: unproven efficacy and neglected safety? J Pain Res. 2013;6:513-529.

[10] Okie S. A flood of opioids, a rising tide of deaths. N Engl J Med. 2010;363:19811985.

[11] Franklin GM, American Academy of Neurology. Opioids for chronic noncancer pain: a position paper of the American Academy of Neurology. Neurology. 2014;83:1277-1284.

[12] Dowell D, Haegerich TM, Chou R. CDC Guideline for Prescribing Opioids for Chronic Pain--United States, 2016. JAMA. 2016;315:1624-1645.

[13] Gilron I, Baron R, Jensen T. Neuropathic pain: principles of diagnosis and treatment. Mayo Clin Proc. 2015;90:532-545. 
[14] McNicol ED, Midbari A, Eisenberg E. Opioids for neuropathic pain. Cochrane Database Syst Rev. 2013;CD006146.

[15] Schwartz S, Etropolski M, Shapiro DY, et al. Safety and efficacy of tapentadol ER in patients with painful diabetic peripheral neuropathy: results of a randomizedwithdrawal, placebo-controlled trial. Curr Med Res Opin. 2011;27:151-162.

[16] Vinik Al, Shapiro DY, Rauschkolb C, et al. A randomized withdrawal, placebocontrolled study evaluating the efficacy and tolerability of tapentadol extended release in patients with chronic painful diabetic peripheral neuropathy. Diabetes Care. 2014;37:2302-2309.

[17] Niesters M, Proto PL, Aarts L, et al. Tapentadol potentiates descending pain inhibition in chronic pain patients with diabetic polyneuropathy. Br J Anaesth. 2014;113:148-156.

[18] Tominaga $\mathrm{Y}$, Koga $\mathrm{H}$, Uchida N, et al. Methodological Issues in Conducting Pilot Trials in Chronic Pain as Randomized, Double-blind, Placebo-controlled Studies. Drug Res (Stuttg). 2016;66:363-370.

[19] Simpson DM, Messina J, Xie F, et al. Fentanyl buccal tablet for the relief of breakthrough pain in opioid-tolerant adult patients with chronic neuropathic pain: a multicenter, randomized, double-blind, placebo-controlled study. Clin Ther. 2007;29:588-601.

[20] Jensen MP, Friedman M, Bonzo D, et al. The validity of the neuropathic pain scale for assessing diabetic neuropathic pain in a clinical trial. Clin J Pain. 2006;22:97103.

[21] Gimbel JS, Richards P, Portenoy RK. Controlled-release oxycodone for pain in diabetic neuropathy: a randomized controlled trial. Neurology. 2003;60:927934.

[22] Sindrup SH, Konder R, Lehmann R, et al. Randomized controlled trial of the combined monoaminergic and opioid investigational compound GRT9906 in painful polyneuropathy. Eur J Pain. 2012;16:849-859.

[23] Arbaiza D, Vidal O. Tramadol in the treatment of neuropathic cancer pain: a double-blind, placebo-controlled study. Clin Drug Investig. 2007;27:75-83.

[24] Simpson RW, Wlodarczyk JH. Transdermal Buprenorphine Relieves Neuropathic Pain: A Randomized, Double-Blind, Parallel-Group, Placebo-Controlled Trial in Diabetic Peripheral Neuropathic Pain. Diabetes Care. 2016;39:1493-1500.

[25] Harrison T, Miyahara S, Lee A, et al. Experience and challenges presented by a multicenter crossover study of combination analgesic therapy for the treatment of painful HIV-associated polyneuropathies. Pain Med. 2013;14:1039-1047. 
[26] Morley JS, Bridson J, Nash TP, et al. Low-dose methadone has an analgesic effect in neuropathic pain: a double-blind randomized controlled crossover trial. Palliat Med. 2003;17:576-587.

[27] Harke H, Gretenkort P, Ladleif HU, et al. The response of neuropathic pain and pain in complex regional pain syndrome I to carbamazepine and sustainedrelease morphine in patients pretreated with spinal cord stimulation: a doubleblinded randomized study. Anesth Analg. 2001;92:488-495.

[28] Lambert DM, Fowler CJ. The endocannabinoid system: drug targets, lead compounds, and potential therapeutic applications. Journal of Medicinal Chemistry. 2005;48:5059-5087.

[29] Elsohly MA, Gul W, Wanas AS, et al. Synthetic cannabinoids: analysis and metabolites. Life Sciences. 2014;97:78-90.

[30] Pacher P, Bátkai S, Kunos G. The endocannabinoid system as an emerging target of pharmacotherapy. Pharmacol Rev. 2006;58:389-462.

[31] Serpell M, Ratcliffe S, Hovorka J, et al. A double-blind, randomized, placebocontrolled, parallel group study of THC/CBD spray in peripheral neuropathic pain treatment. Eur J Pain. 2014;18:999-1012.

[32] Lynch ME, Cesar-Rittenberg P, Hohmann AG. A double-blind, placebocontrolled, crossover pilot trial with extension using an oral mucosal cannabinoid extract for treatment of chemotherapy-induced neuropathic pain. J Pain Symptom Manage. 2014;47:166-173.

[33] Selvarajah D, Gandhi R, Emery CJ, et al. Randomized placebo-controlled doubleblind clinical trial of cannabis-based medicinal product (Sativex) in painful diabetic neuropathy: depression is a major confounding factor. Diabetes Care. 2010;33:128-130.

[34] Nurmikko TJ, Serpell MG, Hoggart B, et al. Sativex successfully treats neuropathic pain characterised by allodynia: a randomised, double-blind, placebo-controlled clinical trial. Pain. 2007;133:210-220.

[35] Toth C, Mawani S, Brady S, et al. An enriched-enrolment, randomized withdrawal, flexible-dose, double-blind, placebo-controlled, parallel assignment efficacy study of nabilone as adjuvant in the treatment of diabetic peripheral neuropathic pain. Pain. 2012;153:2073-2082.

[36] Ellis RJ, Toperoff W, Vaida F, et al. Smoked medicinal cannabis for neuropathic pain in HIV: a randomized, crossover clinical trial. Neuropsychopharmacology. 2009;34:672-680.

[37] Abrams DI, Jay CA, Shade SB, et al. Cannabis in painful HIV-associated sensory neuropathy: a randomized placebo-controlled trial. Neurology. 2007;68:515521. 
[38] Karst M, Salim K, Burstein S, et al. Analgesic effect of the synthetic cannabinoid CT-3 on chronic neuropathic pain: a randomized controlled trial. JAMA. 2003;290:1757-1762.

[39] McCartney CJL, Sinha A, Katz J. A qualitative systematic review of the role of Nmethyl-D-aspartate receptor antagonists in preventive analgesia. Anesth Analg. 2004;98:1385-1400.

[40] Tena B, Gomar C, Rios J. Perioperative epidural or intravenous ketamine does not improve the effectiveness of thoracic epidural analgesia for acute and chronic pain after thoracotomy. Clin J Pain. 2014;30:490-500.

[41] Dualé C, Sibaud F, Guastella V, et al. Perioperative ketamine does not prevent chronic pain after thoracotomy. Eur J Pain. 2009;13:497-505.

[42] Mendola C, Cammarota G, Netto R, et al. S(+)-ketamine for control of perioperative pain and prevention of post thoracotomy pain syndrome: a randomized, double-blind study. Minerva Anestesiol. 2012;78:757-766.

[43] Lynch ME, Clark AJ, Sawynok J, et al. Topical 2\% amitriptyline and $1 \%$ ketamine in neuropathic pain syndromes: a randomized, double-blind, placebo-controlled trial. Anesthesiology. 2005;103:140-146.

[44] Morel V, Joly D, Villatte C, et al. Memantine before Mastectomy Prevents PostSurgery Pain: A Randomized, Blinded Clinical Trial in Surgical Patients. PLoS ONE. 2016;11:e0152741.

[45] Schifitto G, Yiannoutsos CT, Simpson DM, et al. A placebo-controlled study of memantine for the treatment of human immunodeficiency virus-associated sensory neuropathy. J Neurovirol. 2006;12:328-331.

[46] Wiech K, Kiefer R-T, Töpfner S, et al. A placebo-controlled randomized crossover trial of the N-methyl-D-aspartic acid receptor antagonist, memantine, in patients with chronic phantom limb pain. Anesth Analg. 2004;98:408-413.

[47] Nikolajsen L, Gottrup H, Kristensen AG, et al. Memantine (a N-methyl-Daspartate receptor antagonist) in the treatment of neuropathic pain after amputation or surgery: a randomized, double-blinded, cross-over study. Anesth Analg. 2000;91:960-966.

[48] Schmid RL, Sandler AN, Katz J. Use and efficacy of low-dose ketamine in the management of acute postoperative pain: a review of current techniques and outcomes. Pain. 1999;82:111-125.

[49] Niesters $\mathrm{M}$, Martini C, Dahan A. Ketamine for chronic pain: risks and benefits. $\mathrm{Br}$ J Clin Pharmacol. 2014;77:357-367.

[50] Kurdi MS, Theerth KA, Deva RS. Ketamine: Current applications in anesthesia, pain, and critical care. Anesth Essays Res. 2014;8:283-290. 
[51] Kurian R, Raza K, Shanthanna H. A systematic review and meta-analysis of memantine for the prevention or treatment of chronic pain. Eur J Pain. 2019;23:1234-1250.

[52] Anand P, Bley K. Topical capsaicin for pain management: therapeutic potential and mechanisms of action of the new high-concentration capsaicin $8 \%$ patch. British Journal of Anaesthesia. 2011;107:490-502.

[53] Szallasi A, Blumberg PM. Vanilloid (Capsaicin) receptors and mechanisms. Pharmacol Rev. 1999;51:159-212.

[54] Derry S, Moore RA. Topical capsaicin (low concentration) for chronic neuropathic pain in adults. Cochrane Database Syst Rev. 2012;CD010111.

[55] Derry S, Rice AS, Cole P, et al. Topical capsaicin (high concentration) for chronic neuropathic pain in adults. Cochrane Database Syst Rev. 2017;1:CD007393.

[56] Kulkantrakorn K, Lorsuwansiri C, Meesawatsom P. 0.025\% capsaicin gel for the treatment of painful diabetic neuropathy: a randomized, double-blind, crossover, placebo-controlled trial. Pain Pract. 2013;13:497-503.

[57] Kulkantrakorn K, Chomjit A, Sithinamsuwan P, et al. 0.075\% capsaicin lotion for the treatment of painful diabetic neuropathy: A randomized, double-blind, crossover, placebo-controlled trial. J Clin Neurosci. 2019;62:174-179.

[58] Simpson DM, Robinson-Papp J, Van J, et al. Capsaicin 8\% Patch in Painful Diabetic Peripheral Neuropathy: A Randomized, Double-Blind, Placebo-Controlled Study. J Pain. 2017;18:42-53.

[59] Moon J-Y, Lee P-B, Kim Y-C, et al. Efficacy and Safety of $0.625 \%$ and $1.25 \%$ Capsaicin Patch in Peripheral Neuropathic Pain: Multi-Center, Randomized, and Semi-Double Blind Controlled Study. Pain Physician. 2017;20:27-35.

[60] Teixeira MJ, Menezes LMB, Silva V, et al. Liposomal topical capsaicin in postherpetic neuralgia: a safety pilot study. Arq Neuropsiquiatr. 2015;73:237-240.

[61] Campbell CM, Diamond E, Schmidt WK, et al. A randomized, double-blind, placebo-controlled trial of injected capsaicin for pain in Morton's neuroma. Pain. 2016;157:1297-1304.

[62] Paice JA, Ferrans CE, Lashley FR, et al. Topical capsaicin in the management of HIV-associated peripheral neuropathy. J Pain Symptom Manage. 2000;19:45-52.

[63] Frias B, Merighi A. Capsaicin, Nociception and Pain. Molecules. 2016;21:797.

[64] Baron R, Allegri M, Correa-Illanes G, et al. The 5\% Lidocaine-Medicated Plaster: Its Inclusion in International Treatment Guidelines for Treating Localized Neuropathic Pain, and Clinical Evidence Supporting its Use. Pain Ther. 2016;5:149-169. 
[65] Sawynok J. Topical analgesics for neuropathic pain: Preclinical exploration, clinical validation, future development: Topical analgesics for neuropathic pain. EJP. 2014;18:465-481.

[66] Wehrfritzl A, Namerl B, Ihmsenl H, et al. Differential effects on sensory functions and measures of epidermal nerve fiber density after application of a lidocaine patch (5\%) on healthy human skin. European Journal of Pain. 2011;15:907-912.

[67] Derry S, Wiffen PJ, Kalso EA, et al. Topical analgesics for acute and chronic pain in adults - an overview of Cochrane Reviews. Cochrane Database Syst Rev. 2017;5:CD008609.

[68] Palladini M, Boesl I, Koenig S, et al. Lidocaine medicated plaster, an additional potential treatment option for localized post-surgical neuropathic pain: efficacy and safety results of a randomized, placebo-controlled trial. Curr Med Res Opin. 2019;35:757-766.

[69] Kim Y-C, Castañeda AM, Lee C-S, et al. Efficacy and Safety of Lidocaine Infusion Treatment for Neuropathic Pain: A Randomized, Double-Blind, and PlaceboControlled Study. Reg Anesth Pain Med. 2018;43:415-424.

[70] Demant DT, Lund K, Finnerup NB, et al. Pain relief with lidocaine $5 \%$ patch in localized peripheral neuropathic pain in relation to pain phenotype: a randomised, double-blind, and placebo-controlled, phenotype panel study. Pain. 2015;156:2234-2244.

[71] Binder A, Bruxelle J, Rogers P, et al. Topical 5\% lidocaine (lignocaine) medicated plaster treatment for post-herpetic neuralgia: results of a double-blind, placebocontrolled, multinational efficacy and safety trial. Clin Drug Investig. 2009;29:393-408.

[72] Cheville AL, Sloan JA, Northfelt DW, et al. Use of a lidocaine patch in the management of postsurgical neuropathic pain in patients with cancer: a phase III double-blind crossover study (NO1CB). Support Care Cancer. 2009;17:451460.

[73] Ho K-Y, Huh BK, White WD, et al. Topical amitriptyline versus lidocaine in the treatment of neuropathic pain. Clin J Pain. 2008;24:51-55.

[74] Estanislao L, Carter K, McArthur J, et al. A randomized controlled trial of 5\% lidocaine gel for HIV-associated distal symmetric polyneuropathy. J Acquir Immune Defic Syndr. 2004;37:1584-1586.

[75] Meier T, Wasner G, Faust M, et al. Efficacy of lidocaine patch $5 \%$ in the treatment of focal peripheral neuropathic pain syndromes: a randomized, double-blind, placebo-controlled study. Pain. 2003;106:151-158.

[76] Galer BS, Jensen MP, Ma T, et al. The lidocaine patch $5 \%$ effectively treats all neuropathic pain qualities: results of a randomized, double-blind, vehicle- 
controlled, 3-week efficacy study with use of the neuropathic pain scale. Clin J Pain. 2002;18:297-301.

[77] Park J, Park HJ. Botulinum Toxin for the Treatment of Neuropathic Pain. Toxins (Basel). 2017;9.

[78] Ranoux D, Attal N, Morain F, et al. Botulinum toxin type A induces direct analgesic effects in chronic neuropathic pain. Ann Neurol. 2008;64:274-283.

[79] Attal N, de Andrade DC, Adam F, et al. Safety and efficacy of repeated injections of botulinum toxin $A$ in peripheral neuropathic pain (BOTNEP): a randomised, double-blind, placebo-controlled trial. Lancet Neurol. 2016;15:555-565.

[80] Ghasemi M, Ansari M, Basiri K, et al. The effects of intradermal botulinum toxin type a injections on pain symptoms of patients with diabetic neuropathy. J Res Med Sci. 2014;19:106-111.

[81] Chen W-T, Yuan R-Y, Chiang S-C, et al. OnabotulinumtoxinA improves tactile and mechanical pain perception in painful diabetic polyneuropathy. Clin J Pain. 2013;29:305-310.

[82] Yuan RY, Sheu JJ, Yu JM, et al. Botulinum toxin for diabetic neuropathic pain: a randomized double-blind crossover trial. Neurology. 2009;72:1473-1478.

[83] Wei J, Zhu X, Yang G, et al. The efficacy and safety of botulinum toxin type A in treatment of trigeminal neuralgia and peripheral neuropathic pain: A metaanalysis of randomized controlled trials. Brain Behav. 2019;9:e01409.

[84] Machado D, Martimbianco ALC, Bussadori SK, et al. Botulinum Toxin Type A for Painful Temporomandibular Disorders: Systematic Review and Meta-Analysis. J Pain. 2019;

[85] Dong Y, Wu T, Hu X, et al. Efficacy and safety of botulinum toxin type A for upper limb spasticity after stroke or traumatic brain injury: a systematic review with meta-analysis and trial sequential analysis. Eur J Phys Rehabil Med. 2017;53:256-267.

[86] Jo JK, Kim KN, Kim DW, et al. The effect of onabotulinumtoxinA according to site of injection in patients with overactive bladder: a systematic review and metaanalysis. World J Urol. 2018;36:305-317.

[87] Scholz J, Finnerup NB, Attal N, et al. The IASP classification of chronic pain for ICD-11: chronic neuropathic pain. Pain. 2019;160:53-59.

[88] Kerckhove N, Collin A, Condé S, et al. Long-Term Effects, Pathophysiological Mechanisms, and Risk Factors of Chemotherapy-Induced Peripheral Neuropathies: A Comprehensive Literature Review. Front Pharmacol. 2017;8:86.

[89] Gaskell H, Derry S, Stannard C, et al. Oxycodone for neuropathic pain in adults. Cochrane Database Syst Rev. 2016;7:CD010692. 
[90] Derry S, Stannard C, Cole P, et al. Fentanyl for neuropathic pain in adults. Cochrane Database Syst Rev. 2016;10:CD011605.

[91] Cooper TE, Chen J, Wiffen PJ, et al. Morphine for chronic neuropathic pain in adults. Cochrane Database Syst Rev. 2017;5:CD011669.

[92] Duehmke RM, Derry S, Wiffen PJ, et al. Tramadol for neuropathic pain in adults. Cochrane Database Syst Rev. 2017;6:CD003726.

[93] United Nations Office on Drugs and Crime. World drug report 2012. [Internet]. New York: United Nations; 2012 [cited 2020 May 29]. Available from: http://search.ebscohost.com/login.aspx?direct=true\&scope=site \&db=nlebk\&d $b=n l a b k \& A N=464981$.

[94] United Nations Office on Drugs and Crime. International Standards for the Treatment of Drug Use Disorders [Internet]. World Health Organization; 2017 [cited 2020 Jun 2]. Available from: https://www.unodc.org/documents/drugprevention-and-

treatment/UNODC_International_Standards_for_the_Treatment_of_Drug_Use _Disorders_March_17_ebook.pdf.

[95] Grella CE, Lovinger K. 30-year trajectories of heroin and other drug use among men and women sampled from methadone treatment in California. Drug Alcohol Depend. 2011;118:251-258.

[96] Cepeda MS, Fife D, Ma Q, et al. Comparison of the risks of opioid abuse or dependence between tapentadol and oxycodone: results from a cohort study. J Pain. 2013;14:1227-1241.

[97] Faria J, Barbosa J, Moreira R, et al. Comparative pharmacology and toxicology of tramadol and tapentadol. Eur J Pain. 2018;22:827-844.

[98] Aviram J, Samuelly-Leichtag G. Efficacy of Cannabis-Based Medicines for Pain Management: A Systematic Review and Meta-Analysis of Randomized Controlled Trials. Pain Physician. 2017;20:E755-E796.

[99] Bohnert ASB, Ilgen MA. Understanding Links among Opioid Use, Overdose, and Suicide. Ingelfinger JR, editor. N Engl J Med. 2019;380:71-79.

[100] Singh S, Loke YK. Drug safety assessment in clinical trials: methodological challenges and opportunities. Trials. 2012;13:138.

[101] Schulz KF, Altman DG, Moher D, et al. CONSORT 2010 statement: updated guidelines for reporting parallel group randomised trials. BMJ. 2010;340:c332.

[102] Cai X, Gewandter JS, He H, et al. Estimands and missing data in clinical trials of chronic pain treatments: advances in design and analysis. Pain. 2020;161:23082320. 
1 Figure 1: Flow diagram of publication selection

2 


\begin{tabular}{|c|c|c|c|c|c|c|c|c|}
\hline Authors' names & $\begin{array}{l}\text { Study } \\
\text { design }\end{array}$ & $\begin{array}{l}\text { Drug/comparator dose/day (patient number) } \\
\text { Route }\end{array}$ & Duration & Pathology & $\begin{array}{l}\text { List of TEAEs ( } \geq 10 \% \text { of patient) } \\
\text { * different from placebo } \\
\text { ns not statistically different from placebo } \\
\text { " no statistical comparison to placebo }\end{array}$ & $\begin{array}{l}\text { SAEs related to } \\
\text { study drug (\%) }\end{array}$ & \begin{tabular}{|l|} 
Dropout due \\
to TEAEs (\%)
\end{tabular} & $\begin{array}{l}\text { Reference } \\
\text { (PMID) }\end{array}$ \\
\hline $\begin{array}{l}\text { Simpson et al. } \\
2016\end{array}$ & $\begin{array}{l}\text { Parallel-group } \\
\text { Multicenter }\end{array}$ & $\begin{array}{l}\text { Buprenorphine patch } 10-40 \mu \mathrm{g} / \mathrm{h} \text { weekly (93) } \\
\text { Placebo (93) }\end{array}$ & 12 weeks & Diabetic neuropathy & \begin{tabular}{|l|} 
All (93.6) \# \\
Nausea (43.0) \# \\
Constipation (31.2) \#
\end{tabular} & 4.3 & 30.1 & 27311495 \\
\hline $\begin{array}{l}\text { Simpson et al. } \\
2007\end{array}$ & \begin{tabular}{|l|} 
Crossover-group \\
Multicenter
\end{tabular} & $\begin{array}{l}\text { Fentanyl, } 9 \text { breakthrough pain, buccal tablet } 100-800 \mu \mathrm{g}(79) \\
\text { Placebo (79) }\end{array}$ & 3 weeks & $\begin{array}{l}\text { Various peripheral neuropathic } \\
\text { pain }\end{array}$ & \begin{tabular}{|l|} 
All (63.0) \# \\
Dizziness $(13.0)$ \# \\
Nausea $(13.0)$ \# \\
Drowsiness (10.0) \#
\end{tabular} & 1.0 & 11.7 & 17617282 \\
\hline $\begin{array}{l}\text { Harrison et al. } \\
2013\end{array}$ & \begin{tabular}{|l|} 
Crossover-group \\
Multicenter
\end{tabular} & $\begin{array}{l}\text { Methadone } 30 \mathrm{mg} / \text { day (15) } \\
\text { Placebo (15) }\end{array}$ & 4 weeks & HIV-associated neuropathy & All (40.0) \# & 0.0 & 0.0 & 23565581 \\
\hline $\begin{array}{l}\text { Morley et al. } \\
2003\end{array}$ & \begin{tabular}{|l|} 
Crossover-group \\
Multicenter
\end{tabular} & $\begin{array}{l}\text { Methadone } 10 \mathrm{mg} / \text { day (18) } \\
\text { Methadone } 20 \mathrm{mg} / \text { day (18) } \\
\text { Placebo (18) }\end{array}$ & 40 days & $\begin{array}{l}\text { Various peripheral neuropathic } \\
\text { pain }\end{array}$ & \begin{tabular}{|l} 
Methadone $10 \mathrm{mg}$ \\
All (UK) \\
Nausea (36.8) \# \\
Dizziness (31.6) \# \\
Headache (26.3) \# \\
Vomiting (21.1) \# \\
Drowsiness (10.5) \# \\
Pruritus (10.5) \# \\
Constipation (10.5) \# \\
Diarrhea (10.5) \# \\
Sweating (10.5) \# \\
\\
Methadone 20 mg \\
All (UK) \\
Nausea (47.1) \# \\
Dizziness (17.6) \# \\
Drowsiness (17.6) \# \\
Constipation (17.6) \# \\
Sweating (17.6) \# \\
Pruritus (11.7) \# \\
Diarrhea (11.7) \#
\end{tabular} & 0.0 & 22.2 & 14594148 \\
\hline $\begin{array}{l}\text { Harke et al. } \\
2001\end{array}$ & $\begin{array}{l}\text { Parallel group } \\
\text { Monocenter }\end{array}$ & $\begin{array}{l}\text { Morphine SR } 90 \text { mg/day (21) } \\
\text { Placebo (17) }\end{array}$ & 8 days & \begin{tabular}{|l|} 
Neuropathic pain \\
Complex regional pain syndrome I
\end{tabular} & \begin{tabular}{|l|} 
All (90) \# \\
Headache (10) \# \\
Sweating (10) \# \\
Nausea (25) \# \\
Vomiting (15) \# \\
\end{tabular} & UK & 4.7 & 11159256 \\
\hline $\begin{array}{l}\text { Jensen et al. } \\
2006\end{array}$ & $\begin{array}{l}\text { Parallel-group } \\
\text { Multicenter }\end{array}$ & $\begin{array}{l}\text { Oxycodone CR } 10-60 \mathrm{mg} / \text { day (82) } \\
\text { Placebo (77) }\end{array}$ & 6 weeks & Diabetic neuropathy & No safety assessment & No safety assessment & 8.5 & 16340598 \\
\hline $\begin{array}{l}\text { Gimbel et al. } \\
2003\end{array}$ & $\begin{array}{l}\text { Parallel-group } \\
\text { Multicenter }\end{array}$ & $\begin{array}{l}\text { Oxycodone CR 10-60 mg/day (82) } \\
\text { Placebo (77) }\end{array}$ & 6 weeks & Diabetic neuropathy & $\begin{array}{l}\text { All (96.0) \# } \\
\text { Constipation }(42.0) * \\
\text { Drowsiness }(40.0) * \\
\text { Nausea }(36.0)^{*} \\
\text { Dizziness }(32.0) * \\
\text { Pruritus }(24.0) * \\
\text { Vomiting }(21.0) * \\
\text { Dry mouth }(16.0) *\end{array}$ & 4.9 & 5.2 & 12654955 \\
\hline
\end{tabular}




\begin{tabular}{|c|c|c|c|c|c|c|c|c|}
\hline & & & & & $\begin{array}{l}\text { Fatigue (15.0) ns } \\
\text { Headache (11.0) ns }\end{array}$ & & & \\
\hline $\begin{array}{l}\text { Tominaga et al. } \\
2016\end{array}$ & \begin{tabular}{|l|} 
Parallel-group \\
Multicenter
\end{tabular} & $\begin{array}{l}\text { Tapentadol ER 50-500 mg/day (60) } \\
\text { Placebo (31) }\end{array}$ & 12 weeks & \begin{tabular}{|l|} 
Diabetic neuropathy \\
Post-herpetic neuropathic pain
\end{tabular} & \begin{tabular}{|l|} 
All $(86.7) \#$ \\
Nausea (31.7) \# \\
Drowsiness (28.3) \# \\
Constipation (26.7) \# \\
Vomiting (18.3) \# \\
Decreased appetite (15) \# \\
Nasopharyngitis (11.7) \# \\
Drug withdrawal syndrome (10) \#
\end{tabular} & UK & UK & 27224908 \\
\hline \begin{tabular}{|l} 
Niesters et al. \\
2014
\end{tabular} & \begin{tabular}{|l|} 
Parallel-group \\
Monocenter
\end{tabular} & $\begin{array}{l}\begin{array}{l}\text { Tapentadol SR 200-500 mg/day (12) } \\
\text { Placebo (12) }\end{array} \\
\end{array}$ & 4 weeks & Diabetic neuropathy & No safety assessment & No safety assessment & 0.0 & 24713310 \\
\hline \begin{tabular}{|l|} 
Vinik et al. \\
2014
\end{tabular} & $\begin{array}{l}\text { Parallel-group } \\
\text { Multicenter }\end{array}$ & $\begin{array}{l}\text { Tapentadol ER, } 200-500 \text { mg/day (166) } \\
\text { Placebo (152) }\end{array}$ & 12 weeks & Diabetic neuropathy & \begin{tabular}{|l|} 
All (79.5)\# \\
Nausea (21.1)\# \\
Vomiting (12.7)\#
\end{tabular} & 4.8 & 11.4 & 24848284 \\
\hline \begin{tabular}{|l} 
Schwartz et al. \\
2011
\end{tabular} & \begin{tabular}{|l} 
Parallel-group \\
Multicenter
\end{tabular} & \begin{tabular}{|l} 
Tapentadol ER, 200-500 mg/day (199) \\
Placebo (196)
\end{tabular} & 12 weeks & Diabetic neuropathy & $\begin{array}{l}\text { All (70.9)\# } \\
\text { Gastrointestinal disorders (29.1)\# } \\
\text { Nervous system disorders (18.9)\# } \\
\text { Psychiatric disorders (16.8)\# } \\
\text { Respiratory, thoracic and mediastinal disorders } \\
\text { (12.2)\# } \\
\text { Musculoskeletal and connective tissue disorders - } \\
\text { pain (14.3)\# }\end{array}$ & 5.1 & 11.2 & 21162697 \\
\hline $\begin{array}{l}\text { Sindrup et al. } \\
2012\end{array}$ & $\begin{array}{l}\text { Crossover-group } \\
\text { Multicenter }\end{array}$ & $\begin{array}{l}\text { Tramadol } 200-400 \mathrm{mg} / \text { day (64) } \\
\text { Placebo (64) }\end{array}$ & 4 weeks & $\begin{array}{l}\text { Various peripheral neuropathic } \\
\text { pain }\end{array}$ & \begin{tabular}{|l|l|} 
All (UK) \\
Nausea (25.0)\# \\
Constipation (25.0)\# \\
Vomiting (10.7)\#\# \\
Fatigue (26.8)\# \\
Decrease appetite (10.7)\# \\
Dizziness (16.1)\# \\
Headache (12.5)\# \\
Sleep disorder (25.0)\# \\
Pruritus (12.5)\#
\end{tabular} & 1.6 & UK & 22337471 \\
\hline \begin{tabular}{|l|} 
Arbaiza et al. \\
2007
\end{tabular} & \begin{tabular}{|l} 
Parallel-group \\
Monocenter
\end{tabular} & $\begin{array}{l}\text { Tramadol 1-1.5 mg/kg every } 6 \text { hours (18) } \\
\text { Placebo (18) }\end{array}$ & 45 days & $\begin{array}{l}\text { Cancer- or cancer treatment- } \\
\text { related neuropathic pain }\end{array}$ & $\begin{array}{l}\text { All }(67.0) * \\
\text { Nausea/constipation (62.0) \# } \\
\text { Vomiting (39.0) \# }\end{array}$ & 17.0 & 17.0 & 17177582 \\
\hline
\end{tabular}

Table 1: Summary table of opioids.

Route of administration is not provided when administered orally.

* statistically different from placebo; ns not statistically difference from placebo; \# no statistical comparison to placebo; TEAE, treatment-

emergent adverse event; SAEs, serious adverse event; UK, unknown; ER, extended-release; CR, controlled-release; SR, sustained-released. 


\begin{tabular}{|c|c|c|c|c|c|c|c|c|}
\hline Authors' names & $\begin{array}{l}\text { Study } \\
\text { design }\end{array}$ & $\begin{array}{l}\text { Drug/comparator dose/day (patient number) } \\
\text { Route }\end{array}$ & Duration & Pathology & \begin{tabular}{|l|} 
List of TEAEs ( $\geq 10 \%$ of patient) \\
* different from placebo \\
ns not statistically different from placebo \\
"\# no statistical comparison to placebo
\end{tabular} & $\begin{array}{l}\text { SAEs related to } \\
\text { study drug (\%) }\end{array}$ & $\begin{array}{l}\text { Dropout due } \\
\text { to TEAEs (\%) }\end{array}$ & \begin{tabular}{|l} 
Reference \\
(PMID)
\end{tabular} \\
\hline \begin{tabular}{|l} 
Lynch et al. \\
2014
\end{tabular} & $\begin{array}{l}\text { Crossover-group } \\
\text { Monocenter }\end{array}$ & $\begin{array}{l}\text { Tetrahydrocannabinol / cannabidiol (Sativex }{ }^{\oplus} \text { ) 2-12 } \\
\text { inhalations/day (16) } \\
\text { Placebo (16) }\end{array}$ & 4 weeks & $\begin{array}{l}\begin{array}{l}\text { Chemotherapy-induced } \\
\text { peripheral neuropathy }\end{array} \\
\end{array}$ & \begin{tabular}{|l|} 
All (UK) \\
Fatigue (43.8) \# \\
Dizziness (37.5) \# \\
Nausea (37.5) \# \\
Dry mouth (31.3) \# \\
Increased appetite (12.5) \# \\
Diarrhea (12.5) \# \\
Headache (12.5) \# \\
Confusion (12.5) \# \\
\end{tabular} & 0.0 & UK & 23742737 \\
\hline $\begin{array}{l}\text { Serpell et al. } \\
2014\end{array}$ & $\begin{array}{l}\text { Parallel-group } \\
\text { Muticenter }\end{array}$ & $\begin{array}{l}\text { Tetrahydrocannabinol / cannabidiol }(27 \mathrm{mg} / \mathrm{ml} / 25 \mathrm{mg} / \mathrm{ml}, \\
\text { spray of } 100 \mu \mathrm{L} \text { ) oromucosal spray maximum of } 24 \text { sprays/day } \\
\text { (128) } \\
\text { Placebo (118) }\end{array}$ & 15 weeks & Peripheral neuropathic pain & \begin{tabular}{|l|} 
All (UK) \\
Dizziness (39.0) \# \\
Dysgeusia (11.0) \# \\
Nausea (17.0) \# \\
Fatigue (15.0) \#
\end{tabular} & 0.0 & 19.0 & 24420962 \\
\hline \begin{tabular}{|l} 
Toth et al. \\
2012
\end{tabular} & $\begin{array}{l}\text { Parallel-group } \\
\text { Monocenter }\end{array}$ & $\begin{array}{l}\text { Nabilone 1-4 mg/day (13) } \\
\text { Placebo (13) }\end{array}$ & 5 weeks & Diabetic neuropathy & All (54.0) \# & 5.4 & 5.4 & 22921260 \\
\hline $\begin{array}{l}\text { Selvarajah et al. } \\
2010\end{array}$ & $\begin{array}{l}\text { Parallel-group } \\
\text { Monocenter }\end{array}$ & $\begin{array}{l}\text { Tetrahydrocannabinol / cannabidiol ( } 27 \mathrm{mg} / \mathrm{ml} / 25 \mathrm{mg} / \mathrm{ml} \text { ) } \\
\text { (15) } \\
\text { Placebo (15) }\end{array}$ & 12 weeks & Diabetic neuropathy & No safety assessment & No safety assessment & 6.0 & 19808912 \\
\hline \begin{tabular}{|l} 
Ellis et al. \\
2009
\end{tabular} & $\begin{array}{l}\text { Parallel-group } \\
\text { Monocenter }\end{array}$ & $\begin{array}{l}\text { Cannabis cigarette (1-8\% } \Delta-9-\mathrm{THC}) \text { administered in } 4 \text { days } \\
\text { smoking sessions separated by intervals of } 90-120 \mathrm{~min}(16) \\
\text { Placebo (18) }\end{array}$ & 7 weeks & HIV-associated neuropathy & \begin{tabular}{|l|} 
All (UK) \\
Increases in heart rate $(46.0) \#$
\end{tabular} & UK & 12.5 & 18688212 \\
\hline $\begin{array}{l}\text { Nurmikko et al. } \\
2007\end{array}$ & $\begin{array}{l}\text { Parallel-group } \\
\text { Multicenter }\end{array}$ & $\begin{array}{l}\text { Tetrahydrocannabinol / cannabidiol ( } 2.7 \mathrm{mg} / 2.5 \mathrm{mg} \text { ) mean } \\
\text { of } 11 \text { sprays/day (63) } \\
\text { Placebo (62) }\end{array}$ & 5 weeks & HIV-associated neuropathy & \begin{tabular}{|l|} 
All $(91 \%)$ \# \\
Dizziness (28.6) \# \\
Nausea (22.2) \# \\
Fatigue (20.6) \# \\
Dry mouth (17.5) \# \\
Vomiting (12.7) \# \\
\end{tabular} & 1.6 & 18.0 & 17997224 \\
\hline \begin{tabular}{|l|} 
Abrams et al. \\
2007
\end{tabular} & $\begin{array}{l}\text { Parallel-group } \\
\text { Monocenter }\end{array}$ & $\begin{array}{l}\text { Cannabis cigarette (3.56\% } \Delta-9-\mathrm{THC}) 3 / \text { day for } 5 \text { days (25) } \\
\text { Placebo (25) }\end{array}$ & 12 days & HIV-associated neuropathy & \begin{tabular}{|l|} 
All(UK) \\
Anxiety (UK) * \\
Sedation (UK) * \\
Disorientation (UK) * \\
Confusion (UK) * \\
Dizziness (UK) * \\
\end{tabular} & 4.0 & 0.0 & 17296917 \\
\hline \begin{tabular}{|l} 
Karst et al. \\
2003
\end{tabular} & \begin{tabular}{|l|} 
Crossover-group \\
Multicenter
\end{tabular} & $\begin{array}{l}\text { CT-3 1',1'dimethylheptyl- } \Delta 8 \text {-tetrahydrocannabinol-11-oic } \\
\text { acid (capsule) } 40-80 \mathrm{mg} / \text { day (10) } \\
\text { Placebo (11) }\end{array}$ & 1 week & $\begin{array}{l}\text { Various peripheral neuropathic } \\
\text { pain }\end{array}$ & \begin{tabular}{|l|} 
All (UK) * \\
No details on TEAEs frequencies
\end{tabular} & 10.0 & 10.0 & 14519710 \\
\hline
\end{tabular}

Table 2: Summary table of cannabinoids.

Route of administration is not provided when administered orally. 
* statistically different from placebo; ns not statistically different from placebo; \# no statistical comparison to placebo; TEAE, treatmentemergent adverse event; SAEs, serious adverse event; UK, unknown. 


\begin{tabular}{|c|c|c|c|c|c|c|c|c|}
\hline Authors' names & $\begin{array}{l}\text { Study } \\
\text { design }\end{array}$ & $\begin{array}{l}\text { Drug/comparator dose/day (patient number) } \\
\text { Route }\end{array}$ & Duration & Pathology & \begin{tabular}{|l} 
List of TEAEs ( $\geq 10 \%$ of patient) \\
$*$ different from placebo \\
ns not statistically different from placebo \\
" no statistical comparison to placebo
\end{tabular} & $\begin{array}{l}\text { SAEs related to } \\
\text { study drug (\%) }\end{array}$ & $\begin{array}{l}\text { Dropout due } \\
\text { to TEAEs (\%) }\end{array}$ & \begin{tabular}{|l}
$\begin{array}{l}\text { Reference } \\
\text { (PMID) }\end{array}$ \\
\end{tabular} \\
\hline \multicolumn{9}{|l|}{ Ketamine } \\
\hline \begin{tabular}{|l} 
Tena et al. \\
2014
\end{tabular} & $\begin{array}{l}\text { Parallel-group } \\
\text { Monocenter }\end{array}$ & $\begin{array}{l}\text { Ketamine } 0.5 \mathrm{mg} / \mathrm{kg} \text { preincisional }+0.25 \mathrm{mg} / \mathrm{kg} / \mathrm{h} \text { for } 48 \mathrm{~h} \\
\text { epidural infusion }(36 \text { ) } \\
\text { Ketamine } 0.5 \mathrm{mg} / \mathrm{kg} \text { preincisional }+0.25 \mathrm{mg} / \mathrm{kg} / \mathrm{h} \text { for } 48 \mathrm{~h} \text { iv } \\
\text { infusion }(33) \\
\text { Placebo (35) }\end{array}$ & 6 months & Postoperative neuropathic pain & \begin{tabular}{|l} 
All (UK) \\
Ketamine epidural group \\
Nightmares/psychotomimetic effects (25) ns \\
Diplopia (16.7) ns \\
Ketamine iv group \\
Nightmares/psychotomimetic effects (12.1) ns
\end{tabular} & 0.0 & 0.0 & 24281290 \\
\hline $\begin{array}{l}\text { Mendola et al. } \\
2012\end{array}$ & \begin{tabular}{|l|} 
Parallel-group \\
Monocenter
\end{tabular} & $\begin{array}{l}\text { Ketamine } 0.1 \mathrm{mg} / \mathrm{kg} / \mathrm{h} \text { for } 60 \mathrm{~h} \text { iv infusion (32) } \\
\text { Placebo (30) }\end{array}$ & 6 months & Postoperative neuropathic pain & \begin{tabular}{|l} 
All (UK) \\
Pruritus (37) ns \\
Hypotension (37) ns \\
Vomiting (31) ns \\
Nausea (25) ns
\end{tabular} & 0.0 & 0.0 & 22441361 \\
\hline \begin{tabular}{|l} 
Dualé et al. \\
2009
\end{tabular} & \begin{tabular}{|l|} 
Parallel-group \\
Monocenter
\end{tabular} & $\begin{array}{l}\text { Ketamine } 1 \mathrm{mg} / \mathrm{kg} \text { preincisional }+1 \mathrm{mg} / \mathrm{kg} / \mathrm{h} \text { during surgery + } \\
1 \mathrm{mg} / \mathrm{kg} \text { during } 24 \mathrm{~h} \text { iv infusion (42) } \\
\text { Placebo (44) }\end{array}$ & 4 months & Postoperative neuropathic pain & \begin{tabular}{|l} 
All (UK) \\
Dry mouth sensation (51.1) ns \\
Bradypnea (21.1) ns \\
\end{tabular} & 0.0 & 0.0 & 18783971 \\
\hline \begin{tabular}{|l} 
Lynch et al. \\
2005
\end{tabular} & \begin{tabular}{|l|} 
Parallel-group \\
Monocenter
\end{tabular} & $\begin{array}{l}\text { 1\% ketamine } 4 \mathrm{ml} 3 \text { applications/day (22) } \\
\text { Placebo (25) }\end{array}$ & 3 weeks & $\begin{array}{l}\text { Various peripheral neuropathic } \\
\text { pain }\end{array}$ & \begin{tabular}{|l|} 
All $(30.0)$ ns \\
No TEAE $\geq 10 \%$
\end{tabular} & 0.0 & 9.1 & 15983466 \\
\hline \multicolumn{9}{|l|}{ Memantine } \\
\hline \begin{tabular}{|l} 
Morel et al. \\
2016
\end{tabular} & $\begin{array}{l}\text { Parallel-group } \\
\text { Monocenter }\end{array}$ & $\begin{array}{l}\text { Memantine } 20 \mathrm{mg} / \text { day (20) } \\
\text { Placebo (20) }\end{array}$ & 4 weeks & Postoperative neuropathic pain & No TEAE $\geq 10 \%$ & 0.0 & 0.0 & 27050431 \\
\hline $\begin{array}{l}\text { Schifitto et al. } \\
2006\end{array}$ & $\begin{array}{l}\text { Parallel-group } \\
\text { Multicenter }\end{array}$ & $\begin{array}{l}\text { Memantine } 30 \mathrm{mg} / \text { day (24) } \\
\text { Placebo (21) }\end{array}$ & 16 weeks & HIV-associated neuropathy & All (UK) & UK & UK & 16966223 \\
\hline $\begin{array}{l}\text { Wiech et al. } \\
2004\end{array}$ & \begin{tabular}{|l} 
Crossover-group \\
Monocenter
\end{tabular} & $\begin{array}{l}\text { Memantine } 30 \mathrm{mg} / \text { day (8) } \\
\text { Placebo (8) }\end{array}$ & 4 weeks & Phantom Limb Pain & \begin{tabular}{|l} 
All (UK) \\
Nausea (UK) ns \\
Fatigue (UK) ns \\
Dizziness (UK) ns \\
Headache (UK) ns \\
Agitation (UK) ns
\end{tabular} & UK & UK & 14742379 \\
\hline $\begin{array}{l}\text { Nikolajsen et al. } \\
2000\end{array}$ & \begin{tabular}{|l} 
Crossover-group \\
Monocenter
\end{tabular} & $\begin{array}{l}\text { Memantine } 20 \mathrm{mg} / \text { day (19) } \\
\text { Placebo (19) }\end{array}$ & 5 weeks & $\begin{array}{l}\text { Post-traumatic peripheral } \\
\text { neuropathic pain }\end{array}$ & \begin{tabular}{|l|} 
All $(34.5) \#$ \\
Dizziness $(15.8) \#$ \\
Headache (10.5) \#
\end{tabular} & 5.3 & UK & 11004057 \\
\hline
\end{tabular}

Table 3: Summary table of NMDA antagonists (ketamine and memantine).

Route of administration is not provided when administered orally.

* statistically different from placebo; ns not statistically different from placebo; \# no statistical comparison to placebo; TEAE, treatment-

emergent adverse event; SAEs, serious adverse event; UK, unknown. 


\begin{tabular}{|c|c|c|c|c|c|c|c|c|}
\hline Authors' names & $\begin{array}{l}\text { Study } \\
\text { design }\end{array}$ & $\begin{array}{l}\text { Drug/comparator dose/day (patient number) } \\
\text { Route }\end{array}$ & Duration & Pathology & \begin{tabular}{|l|} 
List of TEAEs ( $\geq 10 \%$ of patient) \\
* different from placebo \\
ns not statistically different from placebo \\
\# no statistical comparison to placebo
\end{tabular} & $\begin{array}{l}\text { SAEs related to } \\
\text { study drug (\%) }\end{array}$ & $\begin{array}{l}\text { Dropout due } \\
\text { to TEAEs (\%) }\end{array}$ & $\begin{array}{l}\text { Reference } \\
\text { (PMID) }\end{array}$ \\
\hline \multicolumn{9}{|l|}{ Capsaicin } \\
\hline $\begin{array}{l}\text { Kulkantrakorn et al. } \\
2019\end{array}$ & \begin{tabular}{|l} 
Crossover-group \\
Multicenter
\end{tabular} & $\begin{array}{l}\text { Capsaicin 0.075\% (lotion) } 3 \text { applications/day (21) } \\
\text { Placebo (21) }\end{array}$ & 8 weeks & Diabetic neuropathy & \begin{tabular}{|l|} 
All (UK) \\
Skin reaction $(50.0)^{*}$ \\
Burning sensation $(41.7) *$ \\
Erythema $(11.1) \mathrm{ns}$
\end{tabular} & 0.0 & 19.0 & 30472337 \\
\hline \begin{tabular}{|l} 
Moon et al. \\
2017
\end{tabular} & \begin{tabular}{|l|} 
Parallel-group \\
Multicenter
\end{tabular} & $\begin{array}{l}\text { Capsaicin } 0.625 \% \text { (patch) } 1 \text { or more applications for } 3 \text { days } \\
\text { and 1-day interval (4-day cycle) (16) } \\
\text { Capsaicin } 1.25 \% \text { (patch) } 1 \text { or more applications for } 3 \text { days and } \\
1 \text {-day interval (4-day cycle) (14) } \\
\text { Capsaicin } 0.075 \% \text { (cream) } 3-4 \text { applications/day (16) } \\
\text { Placebo (14) }\end{array}$ & 6 weeks & $\begin{array}{l}\text { Various peripheral neuropathic } \\
\text { pain }\end{array}$ & $\begin{array}{l}\text { Any (46.7) \# } \\
\text { Constipation (2.2) \# } \\
\text { Paresthesia (UK) }\end{array}$ & 0.0 & 2.2 & 28158151 \\
\hline $\begin{array}{l}\text { Simpson et al. } \\
2017\end{array}$ & \begin{tabular}{|l|} 
Parallel-group \\
Multicenter
\end{tabular} & $\begin{array}{l}\text { Capsaicin 8\% (patch) for } 30 \text { min once (186) } \\
\text { Placebo (183) }\end{array}$ & 12-weeks & Diabetic neuropathy & \begin{tabular}{|l} 
All (46.8) \# \\
Burning sensation (14) \# \\
Pain in extremity (10.8) \#
\end{tabular} & 2.2 & 0.0 & 27746370 \\
\hline $\begin{array}{l}\text { Campbell et al. } \\
2016\end{array}$ & $\begin{array}{l}\text { Parallel-group } \\
\text { Multicenter }\end{array}$ & $\begin{array}{l}\text { Capsaicin } 0.1 \mathrm{mg} \text {, single dose injection (30) } \\
\text { Placebo (28) }\end{array}$ & 3 weeks & Morton's neuroma & $\begin{array}{l}\text { All }(50.0) \# \\
\text { Pain in the foot (16.7) \# } \\
\text { Nausea }(13.3) \# \\
\text { Headache (10.0) \# } \\
\text { Peripheral swelling (10.0) \# }\end{array}$ & 0.0 & 0.0 & 26963851 \\
\hline $\begin{array}{l}\text { Teixeira et al. } \\
2015\end{array}$ & \begin{tabular}{|l|} 
Crossover-group \\
Monocenter
\end{tabular} & $\begin{array}{l}\text { Capsaicin 0.025\% (liposomal cream) 2-3/day (13) } \\
\text { Placebo (13) }\end{array}$ & 6 weeks & Post-herpetic neuropathic pain & \begin{tabular}{|l|l|} 
All $(87.5 \%) \#$ \\
Discomfort (56.25\%) ns
\end{tabular} & UK & 0.0 & 25807130 \\
\hline \begin{tabular}{|l} 
Kulkantrakorn et al. \\
2013
\end{tabular} & $\begin{array}{l}\text { Crossover-group } \\
\text { Monocenter }\end{array}$ & $\begin{array}{l}\text { Capsaicin } 0.025 \% \text { (gel) } 2 \text { inches of gel 3-4/day (33) } \\
\text { Placebo (33) }\end{array}$ & 8 weeks & Diabetic neuropathy & $\begin{array}{l}\text { All }(50.0) \# \\
\text { Skin reaction }(14.7) * \\
\text { Hypertension }(33.3) \mathrm{ns}\end{array}$ & UK & 15.2 & 23228119 \\
\hline $\begin{array}{l}\text { Paice } \text { et al. } \\
2000\end{array}$ & $\begin{array}{l}\text { Parallel-group } \\
\text { Multicenter }\end{array}$ & $\begin{array}{l}\text { Capsaicin } 0.075 \% \text { (cream) 4/day (15) } \\
\text { Placebo (11) }\end{array}$ & 4 weeks & HIV-associated neuropathy & No safety assessment & No safety assessment & 33.3 & 10687326 \\
\hline \multicolumn{9}{|l|}{ Lidocaine } \\
\hline $\begin{array}{l}\text { Palladini et al. } \\
2019\end{array}$ & $\begin{array}{l}\text { Parallel-group } \\
\text { Multicenter }\end{array}$ & $\begin{array}{l}\text { Lidocaine 5\% (patch) 12h/day (180) } \\
\text { Placebo (183) }\end{array}$ & 12 weeks & Postoperative neuropathic pain & $\begin{array}{l}\text { All }(52.0) \# \\
\text { Skin reaction (12.8) \# }\end{array}$ & 0.0 & 3.4 & 30614286 \\
\hline $\begin{array}{l}\text { Kim et al. } \\
2018\end{array}$ & $\begin{array}{l}\text { Parallel-group } \\
\text { Monocenter }\end{array}$ & $\begin{array}{l}\text { Lidocaine } 1 \text { intravenous infusion / week (3 mg/kg) (22) } \\
\text { Placebo (21) }\end{array}$ & 4 weeks & $\begin{array}{l}\text { Various peripheral neuropathic } \\
\text { pain }\end{array}$ & All (14.3) ns & 0.0 & 0.0 & 29381569 \\
\hline \begin{tabular}{|l} 
Demant et al. \\
2015
\end{tabular} & \begin{tabular}{|l|} 
Crossover-group \\
Multicenter
\end{tabular} & $\begin{array}{l}\text { Lidocaine 5\% (patch) 12h/day (43) } \\
\text { Placebo (43) }\end{array}$ & 4 weeks & $\begin{array}{l}\text { Various peripheral neuropathic } \\
\text { pain }\end{array}$ & \begin{tabular}{|l|} 
All $(27.9) \#$ \\
Skin reaction (11.6) \#
\end{tabular} & 0.0 & 7.0 & 26090758 \\
\hline \begin{tabular}{|l} 
Binder et al. \\
2009
\end{tabular} & \begin{tabular}{|l|} 
Parallel-group \\
Multicenter
\end{tabular} & $\begin{array}{l}\text { Lidocaine } 5 \% \text { (patch) up to } 3 \text { applications for } 12 \text { h/day (36) } \\
\text { Placebo (35) }\end{array}$ & 2 weeks & Post-herpetic neuropathic pain & All (13.6) \# & UK & 4.5 & 19432499 \\
\hline \begin{tabular}{|l} 
Cheville et al. \\
2009
\end{tabular} & \begin{tabular}{|l|} 
Crossover-group \\
Multicenter
\end{tabular} & $\begin{array}{l}\text { Lidocaine } 5 \% \text { (patch) 18h/day (19) } \\
\text { Placebo (20) }\end{array}$ & 4 weeks & Postoperative neuropathic pain & \begin{tabular}{|l} 
All (UK) \\
Rash-desquamation (21.0) ns \\
Worst toxicity (28.0) ns \\
\end{tabular} & UK & UK & 19142669 \\
\hline $\begin{array}{l}\text { Ho et al. } \\
2008\end{array}$ & $\begin{array}{l}\text { Crossover-group } \\
\text { Multicenter }\end{array}$ & $\begin{array}{l}\text { Lidocaine } 5 \% \text { (gel) 3-5 ml twice a day (35) } \\
\text { Placebo (35) }\end{array}$ & 1 week & $\begin{array}{l}\text { Various peripheral neuropathic } \\
\text { pain }\end{array}$ & \begin{tabular}{|l|l|l} 
All (21.9) ns \\
Itching (14.3) \#
\end{tabular} & 0.0 & 0.0 & 18180637 \\
\hline $\begin{array}{l}\text { Estanislao et al. } \\
2004\end{array}$ & \begin{tabular}{|l|} 
Crossover-group \\
Multicenter
\end{tabular} & $\begin{array}{l}\text { Lidocaine }(5 \%, \text { gel) } 1 / \text { day }(32) \\
\text { Placebo (32) }\end{array}$ & 2 weeks & HIV-associated neuropathy & No details on TEAEs frequencies & 0.0 & 6.3 & 15577414 \\
\hline $\begin{array}{l}\text { Meier et al. } \\
2003\end{array}$ & \begin{tabular}{|l|} 
Crossover-group \\
Multicenter
\end{tabular} & $\begin{array}{l}\text { Lidocaine (5\%, patch) } 12 \mathrm{~h} / \text { day (58) } \\
\text { Placebo (58) }\end{array}$ & 1 week & $\begin{array}{l}\text { Focal peripheral neuropathic } \\
\text { pain syndromes }\end{array}$ & $\begin{array}{l}\text { All (34.5) \# } \\
\text { Rash (17.2) \# }\end{array}$ & 0.0 & 1.7 & 14581122 \\
\hline
\end{tabular}




\begin{tabular}{|c|c|c|c|c|c|c|c|c|}
\hline $\begin{array}{l}\text { Galer et al. } \\
2002\end{array}$ & \begin{tabular}{|l|} 
Parallel-group \\
Multicenter
\end{tabular} & $\begin{array}{l}\text { Lidocaine (5\%, patch) } 1 / \text { day }(67) \\
\text { Placebo (29) }\end{array}$ & 3 weeks & Post-herpetic neuropathic pain & No TEAE $\geq 10 \%$ & UK & UK & 12218500 \\
\hline \multicolumn{9}{|c|}{ Botulinum toxin } \\
\hline $\begin{array}{l}\text { Ranoux et al. } \\
2008\end{array}$ & \begin{tabular}{|l|} 
Parallel-group \\
Monocenter
\end{tabular} & $\begin{array}{l}\text { Botulinum toxin A 20-190 U (intradermal injection) once (15) } \\
\text { Placebo (14) }\end{array}$ & 24 weeks & $\begin{array}{l}\text { Various peripheral neuropathic } \\
\text { pain }\end{array}$ & \begin{tabular}{|l|} 
All (UK) \\
Pain at injection site (86.7) ns
\end{tabular} & UK & 0.0 & 18546285 \\
\hline \begin{tabular}{|l} 
Attal et al. \\
2016
\end{tabular} & $\begin{array}{l}\text { Parallel-group } \\
\text { Multicenter }\end{array}$ & $\begin{array}{l}\text { Botulinum toxin A maximum of } 300 \mathrm{U} \text { (intradermal injection) } \\
\text { one injection for } 12 \text { weeks repeated twice (34) } \\
\text { Placebo (34) }\end{array}$ & 24 weeks & $\begin{array}{l}\text { Various peripheral neuropathic } \\
\text { pain }\end{array}$ & \begin{tabular}{|l|} 
All (UK) \\
Pain at injection (56.0) ns
\end{tabular} & 0.0 & 0.0 & 26947719 \\
\hline $\begin{array}{l}\text { Ghasemi et al. } \\
2014\end{array}$ & \begin{tabular}{|l|} 
Parallel-group \\
Monocenter
\end{tabular} & $\begin{array}{l}\text { Botulinum toxin A } 100 \mathrm{U} \text { (intradermal injection) once (20) } \\
\text { Placebo (20) }\end{array}$ & 3 weeks & Diabetic neuropathy & All $(0.0)$ \# & UK & 0.0 & 24778662 \\
\hline \begin{tabular}{|l} 
Chen et al. \\
2013
\end{tabular} & \begin{tabular}{|l|} 
Crossover-group \\
Monocenter
\end{tabular} & $\begin{array}{l}\text { Botulinum toxin A } 50 \mathrm{U} \text { (intradermal injection) once (20) } \\
\text { Placebo (20) }\end{array}$ & 12 weeks & Diabetic neuropathy & No safety assessment & UK & 0.0 & 23462284 \\
\hline $\begin{array}{l}\text { Yuan et al. } \\
2009\end{array}$ & $\begin{array}{l}\text { Crossover-group } \\
\text { Monocenter }\end{array}$ & $\begin{array}{l}\text { Botulinum toxin A } 50 \mathrm{U} \text { (intradermal injection) once (20) } \\
\text { Placebo (20) }\end{array}$ & 12 weeks & Diabetic neuropathy & No TEAE $\geq 10 \%$ & 0.0 & 0.0 & 19246421 \\
\hline
\end{tabular}

Table 4: Summary table of capsaicin, lidocaine and botulinum toxin.

* statistically different from placebo; ns not statistically different from placebo; \# no statistical comparison to placebo; TEAE, treatmentemergent adverse event; SAEs, serious adverse event; UK, unknown. 


\section{PUBMED extraction : 2,148 publications}

236 publications excluded: publication type

161 reviews and meta-analysis

20 letters to the editor

42 study protocols

10 case reports / case series

3 retractions

1,108 publications excluded: no therapy assessed (epidemiology, physiopathology...)

742 oncology studies

97 endocrinology studies

87 neurology studies

56 infectious diseases studies

37 epidemiology studies

32 anaesthesiology studies

43 other speciality medical studies (rheumatology, surgery, nephrology...)

14 preclinical/animal studies

226 publications excluded: assessment of therapies without medication

158 studies on acupuncture, electrostimulation, cold therapy, magnetic...

38 studies on physical activity, mechanical stimulation...

11 studies on meditation, cognitive therapy, virtual reality...

9 studies on radiofrequency

6 studies on massages

2 studies on physiotherapy

2 studies on other therapy (oxygenotherapy and gene therapy)

\section{Selection of $\mathbf{5 7 8}$ publications : clinical trials on medications}

\section{3 publications excluded: methodology type and objectives}

75 open label studies

57 studies with no placebo or active control

33 not randomized studies

26 studies on acute/subacute treatments or short term follow-up

16 studies on drug in development

16 studies on drug combinations

63 phase 1 / healthy volunteer studies

58 studies on central pain or not peripheral neuropathic pain

9 studies on pharmacokinetic

3 publications excluded: full-text not found

86 publications excluded: antidepressants and antiepileptics

(4 other publications including both antidepressants or antiepileptics and opioids or lidocaine or ketamine were included in the analysis)

86 publications excluded : other drugs ( 3 or less publications by drug)

\section{Inclusion and analysis of 50 publications}

Double-blind, placebo-controlled, randomized clinical trials on opioids (13), lidocaine (9), cannabinoids (8), capsaicin (7), botulinum toxin (5), ketamine (4) and memantine (4) medications 